University of Rhode Island

DigitalCommons@URI

Open Access Master's Theses

1999

\title{
Landscape and Habitat Predictors of Canada Warbler (Wilsonia Canadensis) and Northern Waterthrush (Seiurus noveboracensis) Occurrence in Rhode Island Swamps
}

Nicholas A. Miller

University of Rhode Island

Follow this and additional works at: https://digitalcommons.uri.edu/theses

\section{Recommended Citation}

Miller, Nicholas A., "Landscape and Habitat Predictors of Canada Warbler (Wilsonia Canadensis) and Northern Waterthrush (Seiurus noveboracensis) Occurrence in Rhode Island Swamps" (1999). Open Access Master's Theses. Paper 601.

https://digitalcommons.uri.edu/theses/601

This Thesis is brought to you for free and open access by DigitalCommons@URI. It has been accepted for inclusion in Open Access Master's Theses by an authorized administrator of DigitalCommons@URI. For more information, please contact digitalcommons-group@uri.edu. 
LANDSCAPE AND HABITAT PREDICTORS OF CANADA WARBLER WILSONIA CANADENSIS) AND NORTHERN WATERTHRUSH (SEIURUS NOVEBORACENSIS) OCCURRENCE IN RHODE ISLAND SWAMPS BY

NICHOLAS A. MILLER

A THESIS SUBMITTED IN PARTIAL FULFILLMENT OF THE REQUIREMENTS FOR THE DEGREE OF MASTER OF SCIENCE IN NATURAL RESOURCES 


\section{MASTER OF SCIENCE THESIS}

OF

NICHOLAS A. MILLER

APPROVED:

Thesis Committee

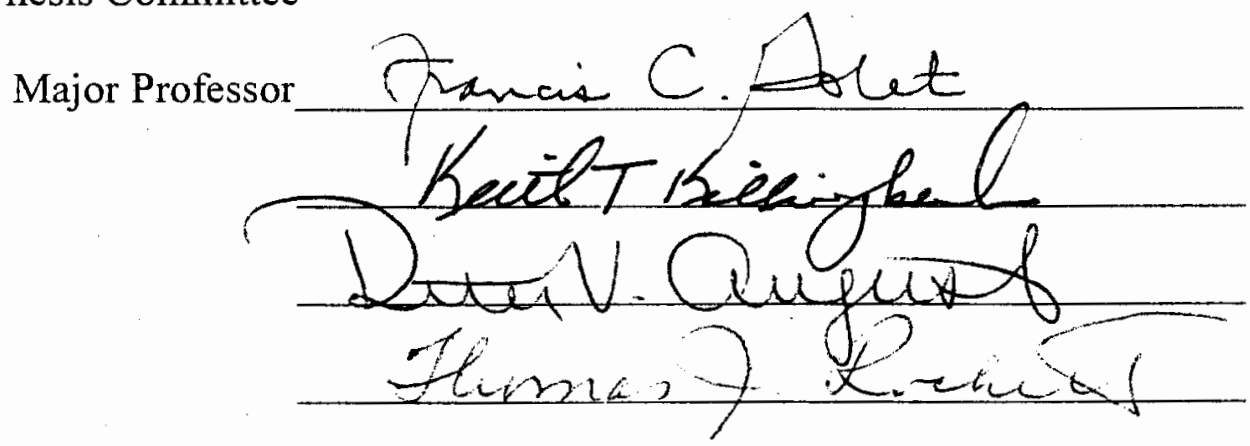

DEAN OF THE GRADUATE SCHOOL

UNIVERSITY OF RHODE ISLAND 


\section{ABSTRACT}

Canada Warblers (Wilsonia canadensis) and Northern Waterthrushes (Seiurus noveboracensis) — both forest-interior, neotropical migrants-are the only breeding bird species in Rhode Island restricted to forested wetlands. Despite continuing alterations of wetlands and surrounding upland landscapes, primarily as a result of urbanization, the factors affecting the distribution of these two species have not previously been investigated. The need for such research is urgent, especially given the long-term decline in Canada Warbler populations in the Northeast. I examined the relative influence of forest habitat characteristics and landscape context on the presence of both species in 80 survey plots located in 44 Rhode Island forested swamps during 1997 and 1998 . I used both univariate and forward stepwise logistic regression analysis to create models for predicting the probability of occurrence, or incidence, of each species. Canada Warbler presence was more strongly linked to landscape features than to habitat characteristics. Incidence of this species was $>0.5$ at points $>300 \mathrm{~m}$ from paved roads, in swamps $>6$ ha, where forest covered $>50 \%$ of the land within $2 \mathrm{~km}$, and where that forest contained $<22 \mathrm{~km}$ of paved roads. Swamps were unlikely to support Canada Warblers where the regional cover of urban and agricultural land was unusually high. At the habitat scale, Canada Warbler incidence exceeded 0.5 when Sphagnum moss cover exceeded $6 \%$ and when there was $<30 \%$ deciduous foliage cover within $0.5 \mathrm{~m}$ of the ground. Incidence of the Northern Waterthrush exceeded 0.5 in swamps $>1.5$ ha and increased with the abundance of additional swamp habitat nearby. Waterthrushes seemed to prefer swamps with $>10 \%$ cover of saturated substrates, with high foliage cover in all strata below $4 \mathrm{~m}$, 
and with high Sphagnum moss cover. The probability of occurrence of this species generally increased with increasing evergreen canopy cover, tree diversity, and basal area of snags. Multivariate models suggested that the occurrence of Canada Warblers in forested wetlands may be predicted accurately from landscape characteristics alone. To accurately predict Northern Waterthrush occurrence, landscape and swamp habitat characteristics must be considered in combination. Current state and Federal laws regulate land use in forested wetlands, but they do not adequately address cumulative permitted losses; nor do they consistently consider the impacts of land use changes in surrounding uplands. Landscape context must be considered in any attempts to conserve these swamp-dependent species. 


\section{ACKNOWLEDGEMENTS}

I am grateful to a long list of people, without whom this thesis research would not have been possible. Dr. Frank Golet, my major professor, tops this list. His constant dedication to conservation and the exploration of wetland ecology have continually inspired me. Since my involvement in this research began he has been both a mentor and a friend.

Dr. Yong Wang provided invaluable assistance. His statistical guidance shaped this thesis, and he devoted many hours to field work. Bob Deegan and Sean Feeley also provided assistance in the field; in addition, they were involved with many other aspects of the project during initial stages, including site selection and landowner contact. I greatly appreciate the efforts and friendship of all three of these people.

Numerous research assistants, interns, and volunteers worked in the field to establish survey plots, measure surface hydrology, and collect vegetation data. I extend my sincere thanks to all of them. Research assistants and interns included Brian ${ }^{\bullet}$ Harrington, Kerry Manire, Michelle Rogne, Lindsay Seward, and Jim Tappero. Volunteers included Mason Adams, Ken Asting, Michael Capirchio, Anna-Marie Carr, Kevin Conde, Howard Cook, Kristin Crary, Matt Devlin, Eric Endrulat, Roma Ferenbaugh, Jennifer Gabel, Corrie Heinz, Jeff Kronick, Andrea LePard, Keri Mella, Kristin Rogne Miller, Amy Mocarsky, Elizabeth Moniz, Nicole Poirier, Craig Pollack, Scott Rush, and Steven Schott.

This study was funded by the Rhode Island Agricultural Experiment Station (McIntire-Stennis Project 969). The University of Rhode Island Coastal Fellowship 
Program provided additional funding. Study site access was granted by the Rhode Island Department of Environmental Management, the Rhode Island Water Resources Board, the Providence Water Supply Board, the Rhode Island Audubon Society, the Narragansett Indian Tribe, Blackstone Valley Electric Company, the U.S. Fish and Wildlife Service, the Girl Scouts of Rhode Island, the Boy Scouts of Rhode Island, and numerous private landowners throughout the State. I greatly appreciate their cooperation and generosity.

Dr. James Heltshe contributed additional statistical advice. I used a GRID AML created by Dr. Matthew Nicholson to measure many landscape variables. Keith Johnson also provided GIS assistance during earlier stages of the study. Dr. Peter August deserves special thanks for providing access to the Environmental Data Center, including its facilities and the technical expertise of its staff.

I thank Drs. Peter August, Keith Killingbeck, and Peter Paton for their insights, advice, and guidance as members (present and former) of my thesis committee. I also wish to thank Dr. Howard Ginsberg for chairing my thesis defense. 


\section{DEDICATION}

I dedicate this thesis to Kristin Rogne Miller, my wife and my best friend, for her patience, help, and encouragement throughout this study. I also dedicate this thesis to my parents, James and Sylvia Miller, who taught me to appreciate forests and landscapes for all they contain. 


\section{PREFACE}

This thesis was written in manuscript format in accordance with the requirements of the Graduate School of the University of Rhode Island. It adheres to the style of the journal Conservation Biology. 


\section{TABLE OF CONTENTS}

Page

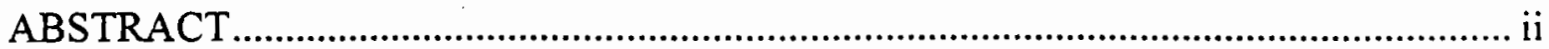

ACKNOWLEDGEMENT ................................................................................

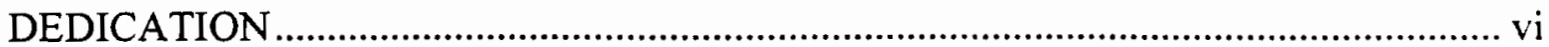

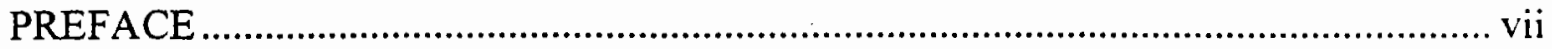

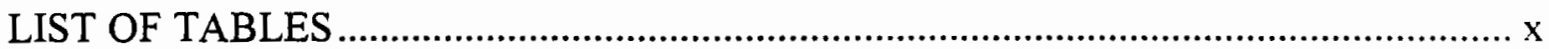

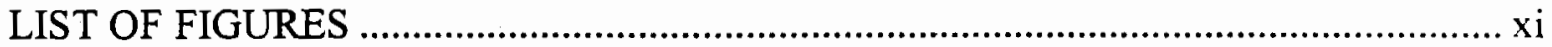

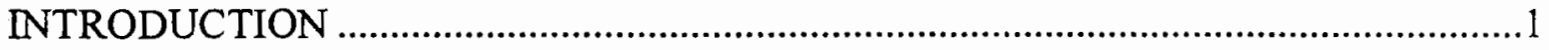

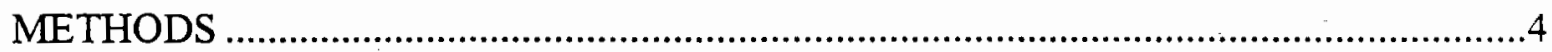

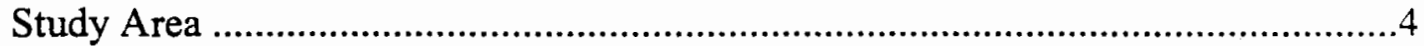

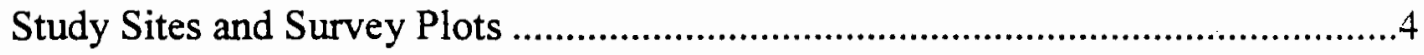

Bird Surveys....................................................................................

Habitat Quantification...........................................................................

Landscape Quantification .................................................................

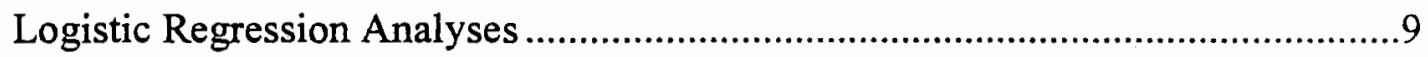

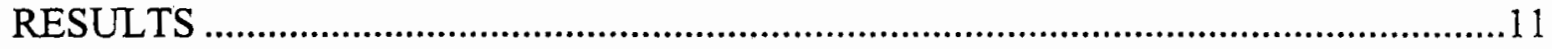

Univariate Models...............................................................................11

Canada Warbler ..................................................................... 11

Northern Waterthrush ......................................................................13

Multivariate Models ..............................................................................15 


\section{TABLE OF CONTENTS (Cont.)}

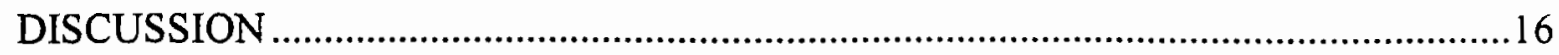

Influence of Landscape Context …................................................................17

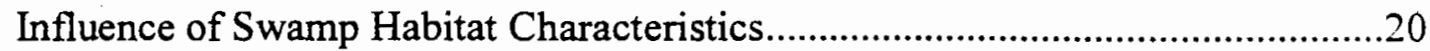

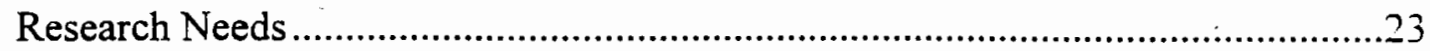

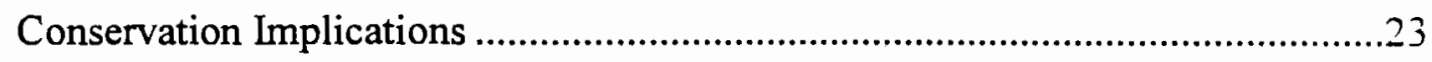

APPENDIX

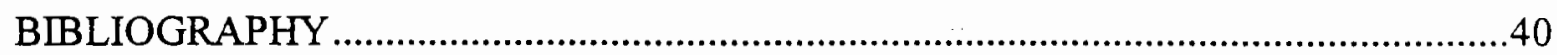




\section{LIST OF TABLES}

Table

1. Stratification of study sites, based on forested wetland size and total forest cover within $2 \mathrm{~km}$ .26

2. Definitions of landscape and habitat variables selected for analyses .27

3. Spearman rank correlation coefficients for independent variables used in the logistic regression analyses .28

4. Characteristics of forested wetland survey plots where Canada Warblers and Northern Waterthrushes were present and where they were absent during the breeding season in Rhode Island, 1997-1998

5. Stepwise logistic regression models explaining presence and absence of Canada Warblers and Northern Waterthrushes at 80 survey points in 44 Rhode Island forested wetlands 


\section{LIST OF FIGURES}

Figure

1. Distribution of very poorly drained forested wetland and other forest cover in the study area

2. Incidence of Canada Warblers in Rhode Island forested wetlands as a function of landscape and habitat variables .32

3. Incidence of Northern Waterthrushes in Rhode Island forested wetlands as a function of landscape and habitat variables 34

4. Spatial correlation analyses of the residuals of multivariate logistic regression models .36

5. Spatial correlation analyses of landscape variables .37

6. Spatial correlation analyses of habitat variables .38

7. Spatial correlation analyses of habitat and species occurrence variables .39 


\section{Introduction}

Forested wetland is the most abundant of all wetland types in the glaciated northeastern United States (Golet et al. 1993); it comprises $78 \%$ of the total area of inland wetlands in the State of Rhode Island (Rhode Island Geographic Information System [RIGIS] data, University of Rhode Island, Kingston). This habitat type supports a diversity of wildlife, including more than 60 species of breeding birds (Golet et al. 1993). Most of the species in this bird community are facultative; i.e., they nest and forage in both wetland and upland habitats (Swift et al. 1984; Golet et al. 1993). In Rhode Island, the only species restricted to forested wetlands are the Northern Waterthrush (Seiurus noveboracensis) and the Canada Warbler (Wilsonia canadensis). Northern Waterthrushes breed only in forested wetlands throughout their range (Bent 1953; Craig 1985). In some regions, Canada Warblers breed in forested upland containing dense shrub cover and streams or wet, mossy areas (Bent 1953; Dunn and Garrett 1997), but in Rhode Island they breed only in swamps (Enser 1992; F.C. Golet, University of Rhode Island Department of Natural Resources Science, pers. comm.). Because Northern Waterthrushes and Canada Warblers breed only in forested wetlands in Rhode Island, and because their breeding habitat continues to be altered by human land use (Golet et al. 1993), the life requisites of these species merit further investigation.

The Canada Warbler and the Northern Waterthrush are neotropical migrants that have been classified as area-sensitive, forest-interior species (Robbins et al. 1989; Freemark and Collins 1992). Forest fragmentation has been identified as a probable cause of the decline of such populations (Robbins et al. 1979; Lynch and Whigham 1984; Robbins et al. 1989). It results in the direct loss of suitable habitat, increased isolation of 
remnant habitat patches, and increased edge effects (Faaborg et al. 1993). The relative amount of edge in a habitat patch increases as patch size decreases, causing forest-interior birds to experience higher rates of nest predation (Wilcove 1985; Paton 1994), brood parasitism (Brittingham and Temple 1983; Paton 1994), and interspecific competition (Ambuel and Temple 1983). Pairing success also decreases near edges (Van Horn et al. 1995). Flather and Sauer (1996) found neotropical migrants to be more sensitive to changes in landscape structure than other groups of birds.

Much of the literature addressing fragmentation impacts is based on studies conducted in regions where forest patches are discrete units embedded in an agricultural or urban matrix (e.g., Ambuel and Temple 1983). In the mid-Atlantic states, Robbins et al. (1989) calculated minimum breeding area requirements based on the incidence of individual bird species in forest patches of varying size. They concluded that Northern Waterthrushes require at least 200 ha of contiguous forest, and Canada Warblers require at least 400 ha. In the extensively forested landscapes of the northeastern United States, forests often constitute the matrix, while agricultural and urban land uses comprise a network of patches. Because Canada Warblers and Northern Waterthrushes are habitat specialists in much of southern New England, it may be necessary to redefine minimum breeding area requirements in terms of patches of suitable forest habitat (i.e., forested wetland). Both species have been observed during the breeding season in swamps as small as 0.5 ha (Merrow 1990). The question then arises whether it is the size of swamp patches or the total abundance of forest in a geographic area that determines the presence of either species. Previous research (Whitcomb et al. 1981; Lynch and Whigham 1984; Askins et al. 1987; Robbins et al. 1989; Freemark and Collins 1992) has indicated that 
the regional abundance of forest can influence both presence and abundance of neotropical migrants.

Landscape context is not the sole determinant of the presence and abundance of forest bird species. Forest habitat characteristics, such as vegetation structure and floristic diversity, also might have a major impact (Freemark and Merriam 1986; Blake and Karr 1987; Robbins et al. 1989), and may be even more important than landscape features (Lynch and Whigham 1984). Similarly, Litwin and Smith (1992) concluded that changes in forest vegetation structure may better explain population changes in selected bird species than changes in surrounding land use patterns.

Knowledge of the relative importance of internal forest habitat characteristics and landscape features in selection of breeding areas by forest birds may be critical to interpreting species-specific population trends. Analyses of Breeding Bird Survey (BBS) data have detected steady declines in Canada Warbler populations both range-wide and in southern New England since the mid-1960's (Sauer et al. 1997), but no trends are apparent for the Northern Waterthrush. These species co-occur in a diversity of forested wetland habitats; therefore, disparate population trends may result primarily from differing sensitivities to landscape-scale processes such as urbanization.

In this study, I examined the relative influence of internal forest habitat characteristics and landscape context on the presence of Canada Warblers and Northern Waterthrushes in Rhode Island forested swamps. Relative effects of the regional abundance of forest, human activity, and swamp area were investigated, and logistic regression models were developed to calculate the probability that an individual swamp would support either species. 


\section{Methods}

\section{Study Area}

The study area comprises the mainland of Rhode Island west of Narragansett Bay (Fig. 1); it encompasses $2,374 \mathrm{~km}^{2}$. Prior to European settlement the Rhode Island landscape was heavily forested; by 1850 , over $80 \%$ of the State had been converted to agriculture (Griffiths 1965). Today, roughly $57 \%$ of the State is covered by forest (RIGIS data), and this forest is once again being fragmented, mainly as a result of urbanization. Forest cover is most extensive in the western half of the study area; it is least extensive in the Providence metropolitan area, at the north end of the Bay. Forested wetlands cover approximately $7 \%$ of the study area (RIGIS data), and are scattered throughout (Fig. 1). Most forested wetlands $>50$ ha are found in the southern one-third of the study area.

\section{Study Sites and Survey Plots}

I selected 44 forested wetland study sites from a statewide GIS coverage using a stratified random sampling scheme. The coverage was created by merging the RIGIS wetlands data set with the RIGIS soils data set. All forested wetlands at least 0.5 ha in size and with a very poorly drained soil drainage class (Wright and Sautter 1979) were considered for selection. Site selection was random, but stratified according to a 21-cell matrix including seven wetland size classes and three forest cover classes (Table 1). Forest cover classes represented the percentage of land within $2 \mathrm{~km}$ of the center of each potential study site that was covered by forest (upland and wetland), as determined by a moving window analysis in the GRID module of ARC/INFO (ESRI 1998a). No forest 
cover data were available for adjacent states; thus, potential sites within $2 \mathrm{~km}$ of the State line were excluded from the selection process. The number of potential study sites was approximately equal among the three forest cover classes. Where possible, $50 \%$ of the sites for each cell in the matrix were selected from the northern half of the study area, and $50 \%$ from the southern half. All randomly selected sites that were within $1 \mathrm{~km}$ of a previously selected site were excluded from consideration.

Birds were surveyed at the center of 8050 -m-radius circular plots. The number of plots per study site varied according to the size of the site (Table 1). Sites between 0.5 and 10 ha contained one plot; sites between 10 and 50 ha contained two plots; and sites > 50 ha contained four plots. To minimize the possibility of detecting the same birds in more than one plot within a site, a minimum distance of $220 \mathrm{~m}$ was maintained between plot centers. Where possible, plot boundaries were located at least $20 \mathrm{~m}$ from upland habitats. Within each plot, four perpendicular radii were flagged, with one 11-m-radius subplot centered halfway $(25 \mathrm{~m})$ out along each radius. Nine sites were too small or too irregularly shaped to contain an entire survey plot; at these sites I established the survey point and at least two entire subplots. Habitat characteristics were sampled in all subplots.

\section{Bird Surveys}

I surveyed birds in 44 of the plots during mid-May through June in 1997; 36 plots were surveyed during late May through early July in 1998. During these 6-week periods, I made two visits to each site between 0520 and 0930 hours. I visited each site once during the first 3 weeks and once during the second 3 weeks. The order of visitation among 
plots surveyed on the same day was reversed during the second visit in an attempt to minimize the influence of time of day on results. I used a fixed-radius, point-count survey technique (Ralph et al. 1995, with modifications). On each visit, I tallied all Northern Waterthrushes and Canada Warblers that were seen or heard during a 10-minute period. Following this, I played Northern Waterthrush songs and calls for 1 minute, followed by 1 minute of observation. Then I played Canada Warbler songs and calls for 1 minute, followed by 1 minute of observation. The order of playback was reversed during the second visit to each survey point. These final 4 minutes of song playback and observation were to enhance detection of territorial birds that did not vocalize during the initial 10 minutes of the survey.

\section{Habitat Quantification}

The areal extent of surface moisture in each subplot was measured during the first 3 weeks of each bird survey period. At $50-\mathrm{cm}$ intervals along each of four $11-\mathrm{m}$ subplot radii, the substrate condition was categorized as surface water, saturated, or dry. Values were combined to estimate the percent cover of each moisture class in each subplot.

All other habitat characteristics were measured in July and August of the survey year. Percent cover of combined herb and shrub foliage was determined for four vertical strata along each of the four subplot radii. The four strata were 0 to $0.5 \mathrm{~m}, 0.5$ to $1 \mathrm{~m}, \mathrm{l}$ to $2 \mathrm{~m}$, and 2 to $4 \mathrm{~m}$. Percent cover was determined in each vertical stratum by noting presence or absence of foliage at $30-\mathrm{cm}$ horizontal intervals. Foliage at each point was recorded as predominantly evergreen or predominantly deciduous. The presence of moss was also recorded at $30-\mathrm{cm}$ intervals and identified as either Sphagnum or "other" moss. 
Tree density, diameter at breast height (dbh), canopy height, and canopy cover were recorded. All trees and saplings within $3 \mathrm{~m}$ of each subplot radius were measured, counted, and identified to species. Trees were defined as woody plants with a dbh of at least $7.6 \mathrm{~cm}$. Saplings were defined as woody plants of tree form with a dbh between 3.0 and $7.6 \mathrm{~cm}$. A clinometer was used to measure the height of one tree near the subplot center that represented the average canopy height for the subplot. A GRS densitometer (Geographic Resource Solutions, Arcata, CA) was used to determine presence or absence of evergreen or deciduous canopy foliage at 1-m intervals along each subplot radius; values were combined to estimate percent canopy cover per subplot. Thickness of the peat layer was measured with a 3-m metal rod at the center of each subplot. All habitat data obtained in subplots were combined to produce average values for each plot.

An index of tree diversity was calculated based on average subplot basal area of individual species within each plot, using the Shannon-Wiener formula (Krebs 1989). An index of foliage evenness, derived from the same formula, was calculated from cover estimates from the four foliage strata.

\section{Landscape Quantification}

Using GIS software (i.e., ARC/NFO [ESRI 1998a] and ArcView [ESRI 1998b]) and RIGIS datasets of wetlands, soils, roads, and land use-land cover, I measured characteristics of each study site and of the surrounding landscape within $2 \mathrm{~km}$ of each bird survey point. The wetlands dataset was produced from 1988 1:24,000-scale panchromatic aerial photographs; wetlands were classified using a modified version of Cowardin et al. (1979). The same set of aerial photos was used to develop the land use- 
land cover dataset. The soils dataset was created from the Soil Survey of Rhode Island (Rector 1981). Roads were digitized from U.S. Geological Survey 7.5-minute topographic maps and Rhode Island Department of Transportation county maps.

Using the GRID module in ARC/INFO (ESRI 1998a), I calculated total forest cover (upland and wetland) within $2 \mathrm{~km}$, and the amount of very poorly drained forested wetland within $2 \mathrm{~km}$, of each survey point. I used the ARC module to compute the area of each study site and the distance from each bird survey point to the nearest paved road. Buffer and clip commands were used in ARC/INFO and ArcView (1998b) to calculate the total length of paved roads in forested areas within $2 \mathrm{~km}$.

There was a strong linear correlation $(r=-0.883)$ between the area of forest land within $2 \mathrm{~km}$ and the combined area of urban and agricultural land uses within $2 \mathrm{~km}$. The residuals (RZ_URB) from a regression of these two variables were used as a measure of the relative amount of urban and agricultural land use for a given amount of forest.

Negative values indicated lower than expected amounts of urban and agricultural land, and positive values indicated higher than expected amounts. There was also a strong linear correlation between the amount of very poorly drained forested wetland within 2 $\mathrm{km}$ and the size of the study site $(\mathrm{r}=0.926)$. I used residuals $(\mathrm{RZ}$ _VFW) from a regression of these two variables as a measure of the relative availability of similar habitat within $2 \mathrm{~km}$ given a swamp of a certain size. Negative values of this new variable indicated lower than expected amounts of very poorly drained forested wetland within 2 $\mathrm{km}$, and positive values indicated higher than expected amounts. 


\section{Logistic Regression Analyses}

I used both univariate logistic regression analysis and forward stepwise logistic regression analysis to create models for predicting the presence of Northern Waterthrushes and Canada Warblers from certain characteristics of forested swamps and surrounding landscapes. These models may also be used to estimate the probability that either species will be present in an individual very poorly drained forested wetland.

I followed suggestions of Hosmer and Lemeshow (1989) in selecting variables to be used in the logistic regression analyses. Out of 120 landscape variables and 67 habitat variables originally considered for analysis, 6 landscape variables and 10 habitat variables were ultimately selected (Table 2). For each species, the selection was based on (1) ecological relevance, (2) low collinearity (Spearman $r<0.50$; Table 3), and (3) the results of Mann-Whitney $U$ tests (Table 4). Those variables that differed $(p<0.20)$ between plots containing and plots not containing each species were considered. To facilitate model comparisons between species, variables selected for both species were entered into each stepwise logistic regression analysis.

Patterns in landscapes occur at a variety of scales (Qi and Wu 1996). Because points closer together may be more similar, the assumption of independence inherent to most statistical tests may be compromised. As a result, variance estimates may be too small and the power of statistical tests may then be artificially inflated, thereby influencing the identification of significant trends (Pendleton 1995). I performed Moran's I analyses using GS ${ }^{+}$(Gamma Design Software 1999), and found that some variables were spatially correlated at certain distances (see Appendix). I decided that, in this study, some degree of spatial correlation could be tolerated because (1) survey points 
were located at least $220 \mathrm{~m}$ apart, which is similar to the minimum distance recommended for avian point count surveys (Ralph et al. 1995); (2) the potentially higher Type I error rate, which may result from autocorrelation, is acceptable for proactive conservation research (Underwood 1997); and (3) the residuals of my multivariate logistic regression models were generally not spatially correlated $(p>0.05)$.

Three multivariate models were developed for each species: one including only landscape variables, one including only habitat variables, and one including both landscape and habitat variables. Variable selection in each of these models was based on log-likelihood change and chi-square tests. Differences in classification accuracy between models were assessed by conducting Pearson chi-square tests on contingency matrices. These matrices contained the number of plots correctly and incorrectly classified for each pair of models compared.

Univariate logistic regression analyses were conducted for both species using each of the 16 variables. These analyses generated probabilities of occurrence, or incidence, for each species over the observed range of values for each variable. The models provided a means of assessing the potential importance of each of the 16 variables to Canada Warblers and Northern Waterthrushes. To determine minimum requirements of either species for each variable, $50 \%$ incidence was used as a cutoff point (see Vickery et al. [1994] for rationale). These univariate graphs should be interpreted with caution because of collinearity among variables (see Table 3 for correlation coefficients). Mann-Whitney U tests were conducted using STATISTICA software (Statsoft, Inc. 1998); all other analyses were performed using SYSTAT software (SPSS, Inc. 1998). 


\section{Results}

Canada Warblers were observed in $53(66.3 \%)$ of the 80 plots surveyed; Northern Waterthrushes were observed in $56(70.0 \%)$ of the plots. The species co-occurred in 42 $(52.5 \%)$ of the plots, and 13 plots $(16.3 \%)$ contained neither species. Individual plots contained up to three Canada Warblers (mean $=0.95, \mathrm{SD}=0.825$ ) and as many as four Northern Waterthrushes $($ mean $=1.24, \mathrm{SD}=1.06)$.

\section{Univariate Models}

\section{Canada Warbler}

With only one exception, the incidence of Canada Warblers was strongly related to landscape characteristics (Figs. 2A - 2F). The occurrence of this species was positively related to the distance from a bird survey point to the nearest paved road (Fig. 2A), the area of a study site (Fig. 2B), and the amount of forest within $2 \mathrm{~km}$ of a survey point (Fig. 2C). In general, Canada Warblers occurred more often than not in habitat distant ( $>300$ m) from paved roads. They rarely occurred within $100 \mathrm{~m}$, and they were almost always present when roads were at least $1 \mathrm{~km}$ away. The size of the forested wetland study site was also positively related to incidence $(p=0.001)$. Canada Warblers occurred more often than not in swamps $>6$ ha in area, but were rarely found in swamps $<1$ ha; incidence exceeded 0.8 in forested wetlands $>100$ ha. The local abundance of forest also appeared to be important to this species. Incidence exceeded 0.5 only when forest cover within $2 \mathrm{~km}$ exceeded $50 \%$. A steady, almost linear increase in incidence occurred as the landscape became increasingly forested. 
Occurrence of Canada Warblers was negatively related to two other landscape variables: the length of paved forest roads within $2 \mathrm{~km}$ (Fig. 2D) and the residual amount of urban and agricultural land in that area (Fig. 2E). Although the birds responded positively to an increase in forest cover (Fig. 2C), incidence declined as those forests became increasingly dissected by roads $(\mathrm{p}=0.006)$. Canada Warbler incidence dropped below 0.5 when the length of paved forest roads within $2 \mathrm{~km}$ exceeded about $22 \mathrm{~km}$. Incidence was similarly affected by the residual amount of urban and agricultural land within the local region $(p=0.010)$. In this case, it dropped below 0.5 when the amount of urban and agricultural land within $2 \mathrm{~km}$ exceeded the expected amount by about $7 \%$. Plots surrounded by lower than expected amounts of these land use types were likely to support Canada Warblers. The residual amount of very poorly drained forested wetland within $2 \mathrm{~km}$ (Fig. 2F) had no impact on Canada Warbler occurrence.

Habitat variables influenced Canada Warbler incidence to a lesser degree than landscape variables. Of the 10 habitat variables examined, only 2-Sphagnum moss cover and deciduous foliage cover within $0.5 \mathrm{~m}$ of the ground-were significantly related to incidence (Figs. $2 \mathrm{G}$ and $2 \mathrm{H}$ ). The probability of occurrence was $>0.5$ whenever Sphagnum cover exceeded about $6 \%$; incidence was $>0.8$ in swamps where Sphagnum covered at least $40 \%$ of the forest floor. Incidence was $0.7-0.8$ when the cover of low deciduous foliage was $<30 \%$; when cover was $>70 \%$, Canada Warblers were more likely to be absent than present.

For certain habitat variables, the probability of occurrence of Canada Warblers was $>0.5$ over the entire range of values observed. Evergreen canopy cover (Fig 2I), tree diversity (Fig. 2J), basal area of snags (Fig. 2K), percent cover of saturated substrate (Fig. 
2L), and peat thickness (Fig. 2M) were examples. None of these variables were significantly related to incidence, but the data suggest a trend toward increasing incidence with increasing values of the variables in each case.

No significant relationship existed between Canada Warbler incidence and either total foliage cover in the 2- to 4-m stratum (Fig. 2N) or the foliage evenness index (Fig. 2O). However, upward trends in probability of occurrence were evident as values of these variables increased. Canada Warbler incidence exceeded 0.5 only when total foliage cover in the $2-$ to $4-\mathrm{m}$ stratum was $>22 \%$. The vast majority of plots surveyed had foliage evenness index values in excess of 0.9 (Table 4); such high values generally indicated high foliage cover in all strata. Fig. 20 suggests that foliage evenness was favorable for Canada Warblers in most of the plots surveyed.

Although the relationship was not significant, Canada Warbler incidence appeared to decrease as surface water cover increased. Figure $2 \mathrm{P}$ suggests that Canada Warblers were more likely to be absent than present in survey plots with $>45 \%$ surface water cover.

\section{Northern Waterthrush}

Only two landscape variables were clearly related to Northern Waterthrush presence: the area of the study site (Fig. 3B) and the residual amount of very poorly drained forested wetland within $2 \mathrm{~km}$ (Fig. 3F). Sites smaller than about 1.5 ha were unlikely to support Northern Waterthrushes. Where the residual amount of very poorly drained forested wetland habitat within $2 \mathrm{~km}$ was $>70$ ha below expected values, the probability of occurrence was also $<0.5$. The distance to the nearest paved road (Fig. 3A), the length of 
paved forest roads within $2 \mathrm{~km}$ (Fig. 3D), and the residual amount of urban and agricultural land within $2 \mathrm{~km}$ (Fig. 3E) had no detectable impact on Northern Waterthrush presence. There was a trend toward higher incidence with increasing amounts of forest within $2 \mathrm{~km}$ (Fig. 3C), but incidence values never fell below 0.5 . Waterthrushes were likely to be present even when regional forest cover values were as low as $25 \%$.

The two habitat variables that were most strongly related to Northern Waterthrush occurrence were foliage evenness (Fig. 3O; $p=0.006$ ) and the percentage cover of saturated substrate (Fig. 3L; $p=0.006$ ). Northern Waterthrushes appeared to require extensive foliage cover in all strata, and plots with evenness values below 0.91 were unlikely to support this species. The steep slope of this relationship (Fig. 3O) underscores the potential importance of this variable. Saturated substrates also appeared to be important for Northern Waterthrushes. When $>30 \%$ of the forest floor was saturated-but not flooded-the probability of Northern Waterthrush occurrence exceeded 0.8 ; when coverage dropped below $10 \%$, this species was more likely to be absent than present.

Five other habitat variables also were positively related to Northern Waterthrush occurrence, but conditions were generally suitable (i.e., incidence $>0.5$ ) across the entire range of each. Evergreen canopy cover (Fig. 3I), tree diversity (Fig. 3J), basal area of snags (Fig. 3K), Sphagnum moss cover (Fig. 3G), and peat thickness (Fig. 3M) were included in this category. Total foliage cover in the 2- to 4-m stratum (Fig. 3N), deciduous foliage cover within $0.5 \mathrm{~m}$ of the ground (Fig. $3 \mathrm{H}$ ), and surface water cover (Fig. 3P) were unrelated to Northern Waterthrush incidence. 


\section{Multivariate Models}

Bird presence was predicted accurately by all of the multivariate models (mean correct classification rate $[C C R]=89.9 \%$, range $=84.9 \%$ to $94.3 \%$; Table 5 ). Differences among the models in overall correct classification rates $($ mean $\mathrm{CCR}=79.8 \%$, range $=$ $73.8 \%$ to $86.3 \%$ ) were primarily due to variation in the models' ability to accurately predict absence (mean CCR $=57.7 \%$, range $=29.2 \%$ to $70.4 \%$ ). Chi-square tests (Table 5) suggest that all models predicted bird presence significantly better than chance alone.

Correct classification rates were highest for both presence and absence in the Canada Warbler model containing only landscape variables (Table 5). This model predicted presence correctly $94.3 \%$ of the time and absence $70.4 \%$ of the time with only four variables. Distance to the nearest paved road was the first variable selected in both the landscape model and the combined model for this species. The combined model also predicted Canada Warbler absence at a $70.4 \%$ rate. Although the habitat model predicted Canada Warbler presence very well $(\mathrm{CCR}=90.6 \%)$, it was only slightly better at predicting absence $(\mathrm{CCR}=55.6 \%)$ than chance alone. Sphagnum moss cover was selected first in the habitat model.

The model combining landscape and habitat variables predicted Northern Waterthrush absence most accurately $(C C R=66.7 \%)$, and therefore produced the best overall classification rate for this species $(82.5 \%)$. This model incorporated five habitat variables and two landscape variables. The five habitat variables-foliage evenness, basal area of snags, tree diversity, surface water cover, and saturated substrate coveralso comprised the habitat model. Both models selected these variables in the same 
order. The habitat model explained presence reasonably well $(\mathrm{CCR}=87.5 \%)$, but predicted absence only slightly better than chance alone $(\mathrm{CCR}=54.2 \%)$. Although the landscape model was the best predictor of Northern Waterthrush presence $(C C R=$ 92.9\%), landscape variables alone were not sufficient to predict absence $(\mathrm{CCR}=29.2 \%)$. The residual amount of very poorly drained forested wetland within $2 \mathrm{~km}$ was the first variable selected in the Northern Waterthrush landscape model; it also appeared in the combined model.

\section{Discussion}

Using multivariate logistic regression analyses, Bolger et al. (1997) recently found that the relative influence of landscape and habitat characteristics on bird species of southern California shrub habitats was species-specific. I obtained similar results in this study of Canada Warblers and Northern Waterthrushes breeding in Rhode Island swamps. These two area-sensitive, forest-interior species selected similar habitats for breeding, but responded differently to many features of those habitats and the surrounding landscape. Landscape context influenced Canada Warbler presence and absence to a greater degree than swamp habitat characteristics, and had higher predictive power for Canada Warblers than for Northern Waterthrushes (Pearson Chi-square $=3.9, \mathrm{df}=1, \mathrm{p}<0.05$ ). The Northern Waterthrush landscape model predicted presence in most cases where birds were actually absent. The Waterthrush habitat model was somewhat more successful than the landscape model in predicting absence. These findings suggest that landscape context may have been adequate for Northern Waterthrushes in most situations, but the birds were absent at certain sites because swamp habitat characteristics were not suitable. 
Overall, the occurrence of this species was best explained by a combination of landscape and habitat variables.

\section{Influence of Landscape Context}

Canada Warblers and Northern Waterthrushes have consistently been categorized as forest-interior, area-sensitive species (Robbins et al. 1989; Freemark and Collins 1992). Robbins et al. (1989) concluded that Canada Warblers required forest patches $\geq 400$ ha for breeding, and Northern Waterthrushes required patches $\geq 200$ ha. Using a similar approach, but redefining patches to include only suitable habitat, I determined that very poorly drained forested wetland patches as small as about 6 ha were suitable for Canada Warblers; Northern Waterthrushes required patches $\geq 1.5$ ha. However, characteristics of surrounding uplands must be considered in conjunction with habitat patch area to accurately assess the landscape-level requirements of either species. Increasing regional abundance of forest cover had a positive influence on Canada Warblers; although not significant, the same trend was apparent for Northern Waterthrushes. Neither species occurs in upland forests during the breeding season in Rhode Island (F.C. Golet, pers. comm.), but upland forests may serve as buffers against edge effects. Although regional forest cover was not a predictor of abundance for either species in linear regression analyses conducted by Robbins et al. (1989), numerous studies have identified this landscape characteristic as an important influence on forest-interior, area-sensitive species in general (Whitcomb et al. 1981; Lynch and Whigham 1984; Askins et al. 1987; Robbins et al. 1989; Freemark and Collins 1992).

As the relative amount of very poorly drained forested wetland within $2 \mathrm{~km}$ increased, the probability of Northern Waterthrush occurrence also increased. Canada 
Warblers, however, were unaffected. This difference in response may reflect differing degrees of habitat specialization over the ranges of these species. Northem Waterthrushes might consistently seek out landscapes rich in forested wetlands because they require this specific habitat type throughout their breeding range. Canada Warblers require microhabitat conditions that, in Rhode Island, are met only by forested wetlands. In other portions of the Canada Warbler's breeding range these conditions (e.g., dense tall shrubs, moss cover) are available in upland forests as well. Thus it is not surprising that total forest cover is a more important cue than forested wetland cover for Canada Warbler habitat selection.

Few studies have investigated the direct influence of urbanization on forestinterior, area-sensitive bird populations. In part, that is because urban and agricultural land uses are usually strongly negatively correlated with the regional abundance of forest. By statistically separating the variability due to forest cover from urban and agricultural land use, I determined that forested swamps were less likely to support Canada Warblers when the extent of these land use types in the surrounding area was unusually high. The specific land uses varied widely, and included residential, commercial, industrial, agricultural, and barren land. For this reason, associated impacts also may range widely. Proximity to residential land may increase rates of nest predation by domestic cats and dogs. Swamps near commercial, industrial, agricultural, and residential centers may be subjected to more chemical and noise pollution. Greater amounts of forest-nonforest edge associated with barren land and farmland may facilitate brood parasitism by Brownheaded Cowbirds (Molothrus ater). Cowbird parasitism frequently poses problems for Canada Warblers, but is only a moderate problem for Northern Waterthrushes (Dunn and 
Garrett 1997). In this study, the occurrence of Northern Waterthrushes was not influenced by the residual amount of urban and agricultural land within $2 \mathrm{~km}$ of a bird survey point; however, there was a trend toward increasing occurrence with an increase in total forest cover within $2 \mathrm{~km}$.

Proximity to paved roads did not affect Northern Waterthrushes, but was the most important landscape variable for Canada Warblers. Similarly, the total length of paved roads in nearby forests was negatively related to the occurrence of Canada Warblers, but was unrelated to Northern Waterthrush occurrence. The total length of paved roads within forests serves as a more subtle indicator of human impact than the area of urban and agricultural lands alone. Many authors (e.g., Askins et al. 1987, Robbins et al. 1989) have considered the regional abundance of forest to be an indicator of low human impact. Distance from roads may be a more direct measure. In a review of research addressing ecological impacts of roads, Forman and Alexander (1998) identified a number of possible causes for road avoidance. These included songbird sensitivity to increased decibel levels and increased visual disturbance, pollution levels, and predator densities near roads. Local changes in hydrology caused by roads may also negatively impact the ground-nesting Canada Warbler. Reijnen et al. (1995) reported decreased densities of particularly sensitive woodland bird populations within $305 \mathrm{~m}$ of roads with traffic rates of up to 10,000 vehicles per day. This distance corresponds well with the distance from roads at which the probability of Canada Warbler occurrence fell below 0.5 in the current study. 


\section{Influence of Swamp Habitat Characteristics}

Hydrology controls most characteristics and functions of wetlands, including habitat conditions and wildlife communities supported by those habitats (Mitsch and Gosselink 1993). Robbins et al. (1989) developed a very coarse moisture gradient variable by classifying forests surveyed according to the moisture associations of the dominant tree species. This variable was selected second in their linear regression model designed for predicting Canada Warbler numbers at a site; it was the first variable selected for Northern Waterthrushes in that study. Many other descriptions of habitat requirements for both species (e.g., Bent 1953; Craig 1985; Curson et al. 1994) highlight moist, even swampy conditions. I detected a strong positive relationship between Northern Waterthrushes and the extent of saturated substrates. Waterthrushes forage for insects, crustaceans, and mollusks by flipping over leaves around the perimeter of surface water pools (Craig 1984) and in saturated zones (pers. obs.). Although no relationship between Northern Waterthrush occurrence and the percent cover of surface water was evident in univariate analyses, multivariate models suggested that this variable had a positive influence; swamps with extensive surface water (e.g., $>45 \%$ ) were unlikely to support Canada Warblers.

Nest site availability may be a key factor limiting habitat suitability for either species. Canada Warblers sometimes build nests in tree stumps or exposed roots of downed trees, but usually in small clumps of Sphagnum moss (Curson et al. 1994; Dunn and Garrett 1997; F. Golet, pers. comm.). Percent cover of Sphagnum had the lowest pvalue (0.008) of all habitat variables in the Canada Warbler univariate logistic regression analyses, and it was the first variable selected in the multivariate habitat model. Northern 
Waterthrushes use moss to line nests (Dunn and Garrett 1997), but they usually build nests in stump cavities or in the exposed root masses of downed trees (Curson et al. 1994: Dunn and Garrett 1997). Northern Waterthrush nests are generally constructed within 60 $\mathrm{cm}$ of the ground, while Canada Warbler nests typically are built directly on the ground or within $15 \mathrm{~cm}$ (Ehrlich et al. 1988). This difference in height might explain the lower frequency of occurrence of Canada Warblers at sites with extensive surface water. The availability of potential nest sites was not assessed in this study. Incorporation of data on nest-site availability (e.g., presence of windthrown trees) in the multivariate models might have enhanced their ability to predict Northern Waterthrush absence.

Dense shrub and herb layers provide foraging habitat and protection from predators for many species of woodland birds (Golet et al. 1993). Extensive shrub cover has been identified as a requirement of Northem Waterthrushes (Bent 1953; Craig 1985) and Canada Warblers (Curson et al. 1994). Shrub and herb layers are often denser in forested wetlands than in surrounding forested uplands (Golet et al. 1993).

Characteristics of foliage cover within $4 \mathrm{~m}$ of the ground influenced both species in the current study, particularly Northern Waterthrushes. Foliage evenness was a significant predictor of Northern Waterthrush occurrence in all analyses conducted, and appeared in one of the Canada Warbler multivariate models. Although such indices have the potential to confound abundance with distribution (Krebs 1989), in this study high values of this index generally indicated high foliage cover in all layers, while low values indicated sparse cover in certain layers. Because of the very small range of values observed for this variable, even slight changes were readily apparent in the field (pers. obs.). Canada Warbler incidence was $>0.5$ where foliage cover exceeded $22 \%$ in the 2 - 
to 4-m stratum. This insectivorous species gleans and hawks for insects at all levels within tall shrubs (Curson et al. 1994; pers. obs.). A negative relationship existed between Canada Warbler occurrence and deciduous foliage cover within $0.5 \mathrm{~m}$ of the ground. Robbins et al. (1989) also found that Canada Warblers prefer sites with sparser ground cover. As a ground-nesting species, Canada Warblers may prefer an open ground layer to enhance visibility of approaching predators.

Northern Waterthrushes and Canada Warblers both occurred in deciduous, mixed, and evergreen swamps throughout the study area. However, evergreen or mixed swamps appeared more likely to support breeding populations of both species than deciduous swamps. For example, a positive relationship was apparent between Northern Waterthrush occurrence and evergreen canopy cover. A similar, but nonsignificant, trend was detected for Canada Warblers. There were comparable trends for both species for three other variables that, in turn, were positively correlated with evergreen canopy cover; these included tree diversity $(r=0.499, p<0.001)$, basal area of snags $(r=0.456$. $\mathrm{p}<0.001)$, and peat thickness $(\mathrm{r}=0.462, \mathrm{p}<0.001)$. In combination, high values for all four of these features create a typical profile of evergreen or mixed forested swamps in Rhode Island. Preference for mixed or evergreen forests has been reported previously for Northern Waterthrushes (Craig 1985; Robbins et al. 1989), but not for Canada Warblers. Evergreen swamps, composed primarily of Atlantic white cedar (Chamaecyparis thyoides), white pine (Pinus strobus), or eastern hemlock (Tsuga canadensis), are relatively scarce in Rhode Island; only $15 \%$ of forested wetlands in the study area are evergreen (RIGIS data). 


\section{Research Needs}

Knowledge of general habitat requirements is often sufficient to explain the presence of a species at a certain location. The challenge in constructing accurate predictive models lies in identifying the characteristics that explain absence. Canada Warblers were generally excluded from sites near paved roads and from sites with surrounding uplands subjected to encroaching urbanization. Nest site availability may be a key limiting factor for Northern Waterthrushes; however, this habitat feature was not assessed in this study.

Wetland hydrology may be very dynamic (Mitsch and Gosselink 1993). Annual fluctuations in the local water table may affect many aspects of wetlands, including wildlife populations. Future research should investigate the influence of annual variations in saturated substrate and surface water cover on breeding habitat selection by Canada Warblers and Northern Waterthrushes.

The mere presence of birds at a site does not necessarily indicate that those birds are breeding successfully (Wenny et al. 1993; Van Horn et al. 1995). Future research should evaluate nesting or pairing success to distinguish between source and sink populations of these species. It would also be useful, for management purposes, to examine the effects of specific human land uses on each species. The urban and agricultural land use variable employed in this study comprised a broad range of land use types.

\section{Conservation Implications}

Current state and Federal regulations protect most forested wetland habitat, but they do not adequately address cumulative permitted losses (Gosselink and Lee 1989). Impacts 
to wetlands from land use changes in bordering uplands are often regulated through the establishment of buffer zones (Golet et al. 1993), but the broader impacts of urbanization at the landscape scale cannot be addressed effectively by wetland regulations. In this study, the likelihood of encountering a Canada Warbler or a Northern Waterthrush increased with the size of the swamp, but the probability of occurrence for both species exceeded 0.5 even in swamps as small as 6 ha; both species were observed in sites as small as 0.8 ha. Landscape context must be considered in any attempts to conserve these swamp-dependent species. Canada Warblers appear to prefer heavily forested landscapes that are relatively undisturbed by human activity. Such conditions are becoming increasingly scarce as urbanization proceeds. The current decline in Canada Warbler populations (Sauer et al. 1997) may be a result of these land use changes. Northern Waterthrushes seem to be influenced more by the abundance of additional very poorly drained forested wetland habitat nearby. Increased protection of mixed and evergreen swamps, which are relatively rare in this region, may benefit both species.

The occurrence of Canada Warblers in forested wetlands may be predicted accurately from landscape characteristics alone. If appropriate GIS datasets are available, this approach would be much more efficient than conducting field surveys, and should produce comparable results. To accurately predict Northern Waterthrush occurrence, landscape and swamp habitat characteristics must be considered in combination. 


\section{APPENDIX}

\section{Spatial Correlation Analyses of Multivariate Logistic Regression Model Residuals, and of Landscape, Habitat, and Species Occurrence Variables}

The results of spatial correlation analyses are presented for the residuals of my multivariate logistic regression models (Fig. 4), and for landscape-scale variables (Fig. 5), habitat variables (Figs. 6 and 7A - 7D), and species occurrence variables (Figs. 7E7F), using Moran's I analyses. Moran's I Coefficient is defined as follows (Gamma Design Software 1999):

$$
\begin{aligned}
& I(h)=N(h) \sum \sum z_{i} z_{j} / \sum z_{i}^{2} \\
& \text { where: } I(h)=\text { autocorrelation for interval distance class } h ; \\
& z_{i}=\text { the measured sample value at point } i \\
& z_{j}=\text { the measured sample value at point } i+h .
\end{aligned}
$$

Values of this statistic range from -1.0 to +1.0 and can be interpreted similarly to Pearson's Product Moment correlation statistic. 
Table 1. Stratification of study sites, based on forested wetland size and total forest cover within $2 \mathrm{~km}$.

\begin{tabular}{|c|c|c|c|c|c|c|c|c|c|}
\hline \multirow{3}{*}{$\begin{array}{c}\text { Swamp } \\
\text { size class (ha) }\end{array}$} & \multirow[b]{3}{*}{ Plots $^{b} /$ site } & \multicolumn{6}{|c|}{ Forest cover ${ }^{a}$} & \multirow[b]{3}{*}{ Total sites } & \multirow[b]{3}{*}{ Total plots } \\
\hline & & \multicolumn{2}{|c|}{$0.50 \%$} & \multicolumn{2}{|c|}{$50-75 \%$} & \multicolumn{2}{|c|}{$75-100 \%$} & & \\
\hline & & Sites & Plots & Sites & Plots & Sites & Plots & & \\
\hline $0.5-5$ & 1 & 4 & 4 & 4 & 4 & 4 & 4 & 12 & 12 \\
\hline $5-10$ & 1 & 4 & 4 & 4 & 4 & 4 & 4 & 12 & 12 \\
\hline $10-20$ & 2 & 2 & 4 & 2 & 4 & 2 & 4 & 6 & 12 \\
\hline $20-50$ & 2 & 2 & 4 & 2 & 4 & 2 & 4 & 6 & 12 \\
\hline $50-100$ & 4 & 1 & 4 & 1 & 4 & 1 & 4 & 3 & 12 \\
\hline $100-200$ & 4 & 0 & 0 & 2 & 8 & 0 & 0 & 2 & 8 \\
\hline \multirow{2}{*}{$200-400$} & 4 & 0 & 0 & 2 & 8 & 1 & 4 & 3 & 12 \\
\hline & Totals & 13 & 20 & 17 & 36 & 14 & 24 & 44 & 80 \\
\hline
\end{tabular}

${ }^{a}$ Total forest cover (upland and wetland) within a $2-\mathrm{km}$ radius of the center of each swamp.

${ }^{b}$ Bird survey plots were circular, with a 50-m radius. 
Table 2. Definitions of landscape and habitat variables selected for analyses.

\begin{tabular}{|c|c|}
\hline Variable & Definition \\
\hline \multicolumn{2}{|l|}{ Landscape } \\
\hline D_RDS & Distance $(\mathrm{km})$ to the nearest paved road. \\
\hline LOGAREA & Log base 10 of area (ha) of the very poorly drained forested wetland study site. \\
\hline FOR2K & Percent cover of forest (upland and wetland) within $2 \mathrm{~km}$. \\
\hline FORESTRD & Total length $(\mathrm{km})$ of paved roads in forested areas within $2 \mathrm{~km}$. \\
\hline RZ_URB & $\begin{array}{l}\text { Residual value of combined percent cover of urban and agricultural land uses within } 2 \mathrm{~km} \text {, after variability due to FOR2K } \\
\text { was removed. }\end{array}$ \\
\hline RZ_VFW & $\begin{array}{l}\text { Residual value of total area of very poorly drained forested wetland within } 2 \mathrm{~km} \text {, after variability due to study site area was } \\
\text { removed. }\end{array}$ \\
\hline \multicolumn{2}{|l|}{ Habitat } \\
\hline CCEVG & Percent cover of evergreen tree canopy. \\
\hline TREEDIV & $\begin{array}{l}\text { Index of tree diversity, based on average basal area of individual species within each plot, using the Shannon-Wiener } \\
\text { formula (Krebs 1989). A value of zero indicates the presence of only one species. }\end{array}$ \\
\hline BA_SNAG & Basal area $\left(\mathrm{m}^{2} / \mathrm{ha}\right)$ of snags. \\
\hline FC2-4 & Percent cover of deciduous and evergreen foliage, $2-4 \mathrm{~m}$ from ground. \\
\hline $\mathrm{FCD}<0.5$ & Percent cover of deciduous shrub and herb foliage, $0-0.5 \mathrm{~m}$ from ground. \\
\hline FEI & $\begin{array}{l}\text { Index of foliage evenness, created from cover estimates from four vertical strata }(0-0.5 \mathrm{~m}, 0.5-1 \mathrm{~m}, 1-2 \mathrm{~m}, 2-4 \mathrm{~m}) \text {, } \\
\text { based on the Shannon-Wiener formula. Low values indicate low evenness and low overall foliage cover; high values indicate } \\
\text { high evenness and high overall foliage cover. }\end{array}$ \\
\hline W & Percent cover of surface water. \\
\hline $\mathbf{S}$ & Percent cover of saturated substrates. \\
\hline MOSS & Percent cover of Sphagnum moss. \\
\hline PEAT & Thickness $(\mathrm{cm})$ of peat layer. \\
\hline
\end{tabular}


Table 3. Spearman rank correlation coefficients for independent variables used in the logistic regression analyses.

\begin{tabular}{|c|c|c|c|c|c|c|c|c|c|c|c|c|c|c|c|c|}
\hline Variable $^{a}$ & 1 & 2 & 3 & 4 & 5 & 6 & 7 & 8 & 9 & 10 & 11 & 12 & 13 & 14 & 15 & 16 \\
\hline 1. D_RDS & 1.000 & & & & & & & & & & & & & & & \\
\hline 2. LOGAREA & 0.454 & 1.000 & & & & & & & & & & & & & & \\
\hline 3. FOR2K & 0.399 & 0.043 & 1.000 & & & & & & & & & & & & & \\
\hline 4. FORESTRD & -0.398 & -0.302 & 0.084 & 1.000 & & & & & & & & & & & & \\
\hline 5. RZ URB & -0.329 & -0.182 & -0.053 & 0.382 & 1.000 & & & & & & & & & & & \\
\hline 6. RZ_VFW & -0.091 & 0.295 & -0.224 & -0.169 & -0.193 & 1.000 & & & & & & & & & & \\
\hline 7. MOSS & 0.283 & -0.157 & 0.307 & 0.044 & -0.152 & -0.079 & 1.000 & & & & & & & & & \\
\hline 8. CCEVG & 0.301 & 0.285 & 0.417 & -0.048 & 0.099 & -0.007 & 0.201 & 1.000 & & & & & & & & \\
\hline 9. BA_SNAG & 0.381 & 0.331 & 0.233 & -0.262 & -0.067 & 0.088 & 0.113 & 0.456 & 1.000 & & & & & & & \\
\hline 10. $\mathrm{FCD}<0.5$ & -0.339 & -0.324 & -0.131 & 0.299 & -0.014 & -0.157 & 0.060 & -0.397 & -0.407 & 1.000 & & & & & & \\
\hline 11. FC2-4 & 0.058 & 0.064 & 0.288 & 0.042 & -0.059 & -0.102 & 0.082 & -0.094 & -0.070 & -0.221 & 1.000 & & & & & \\
\hline 12. $\mathrm{W}$ & -0.217 & -0.321 & -0.091 & 0.229 & 0.090 & 0.010 & 0.283 & -0.173 & -0.214 & 0.075 & 0.138 & 1.000 & & & & \\
\hline 13. TREEDIV & 0.136 & 0.206 & 0.354 & 0.038 & 0.137 & -0.097 & 0.017 & 0.499 & 0.178 & 0.019 & -0.086 & -0.278 & 1.000 & & & \\
\hline 14. FEI & -0.050 & 0.102 & -0.105 & -0.041 & -0.126 & 0.100 & 0.179 & -0.032 & -0.019 & 0.394 & -0.239 & -0.026 & 0.053 & 1.000 & & \\
\hline 15. $\mathrm{S}$ & -0.105 & -0.123 & -0.054 & 0.057 & 0.067 & -0.031 & 0.471 & -0.023 & -0.027 & 0.182 & 0.061 & 0.224 & -0.123 & 0.350 & 1.000 & \\
\hline 16. PEAT & 0.053 & 0.184 & 0.017 & 0.024 & 0.239 & -0.191 & -0.117 & 0.462 & 0.116 & -0.276 & 0.064 & -0.258 & 0.128 & 0.195 & 0.190 & 1.000 \\
\hline
\end{tabular}

${ }^{a}$ Variable codes defined in Table 2 . 
Table 4. Characteristics of forested wetland survey plots where Canada Warblers and Northern Watertlirushes were present and where they were absent during the breeding season in Rhode Island, 1997-1998.

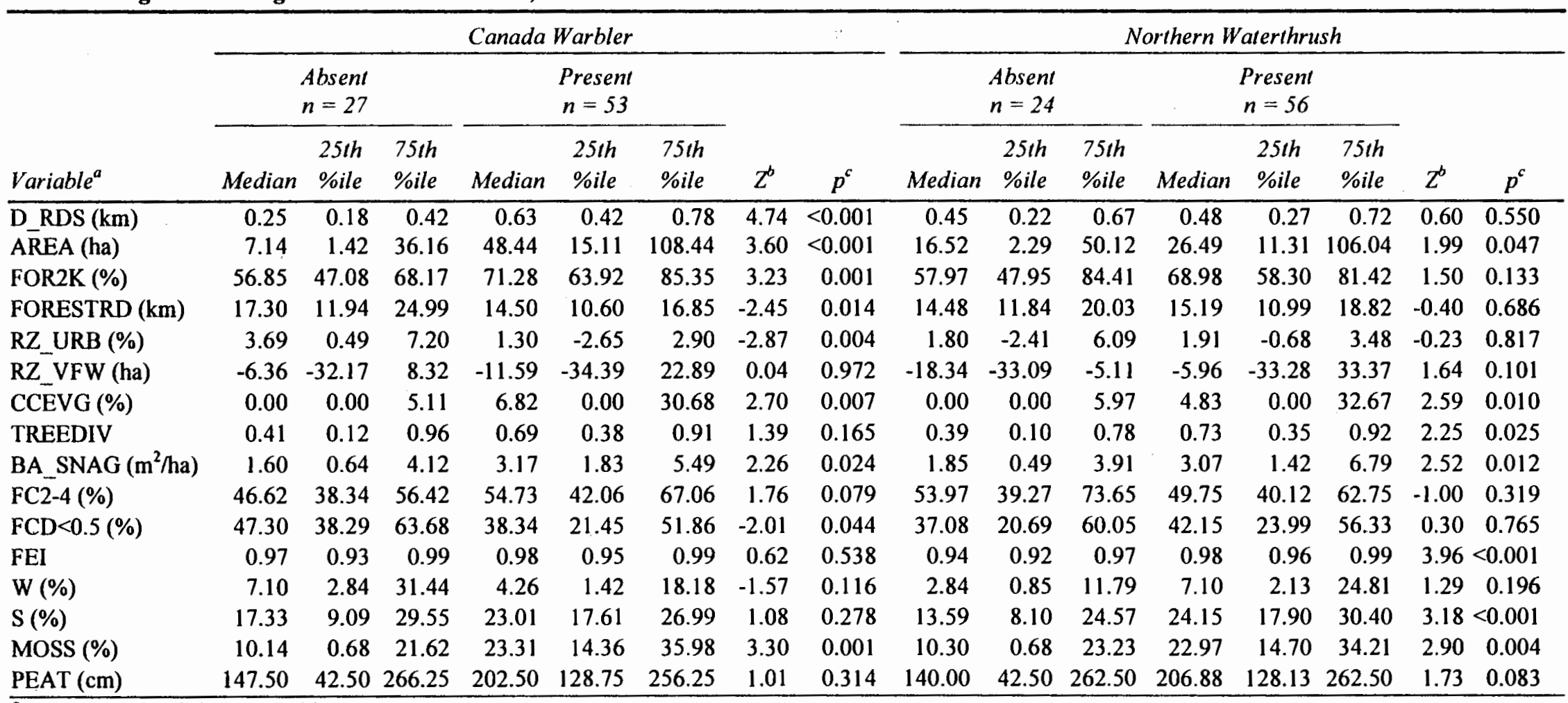

Variable codes defined in Table 2.

${ }^{b}$ Adjusted Z-scores from Mann-Whitney $U$ test.

'P-values from Mann-Whitney U test. 
Table 5. Stepwise logistic regression models explaining presence and absence of Canada Warblers and Northern Waterthrushes at 80 survey points in 44 Rhode Island forested wetlands. Models were developed from landscape variables only, habitat variables only, and landscape and habitat variables combined. Variable codes are defined in Table 2.

\begin{tabular}{|c|c|c|c|c|c|c|}
\hline \multirow[b]{2}{*}{ Variable selected } & \multicolumn{6}{|c|}{ Models } \\
\hline & $\begin{array}{l}\text { Canada } \\
\text { Warbler } \\
\text { landscape }\end{array}$ & $\begin{array}{l}\text { Canada } \\
\text { Warbler } \\
\text { habitat }\end{array}$ & $\begin{array}{c}\text { Canada } \\
\text { Warbler } \\
\text { combined }\end{array}$ & $\begin{array}{c}\text { Northern } \\
\text { Waterthrush } \\
\text { landscape }\end{array}$ & $\begin{array}{c}\text { Northern } \\
\text { Waterthrush } \\
\text { habitat }\end{array}$ & $\begin{array}{c}\text { Northern } \\
\text { Waterthrush } \\
\text { combined }\end{array}$ \\
\hline Constant & -4.749 & 1.398 & -29.003 & -1.305 & -26.502 & -24.200 \\
\hline 1 & $\begin{array}{c}\text { D_RDS } \\
3.812^{\mathrm{a}}\end{array}$ & $\begin{array}{r}\text { MOSS } \\
0.061\end{array}$ & $\underset{\overline{6} .243}{\text { D_RDS }}$ & $\begin{array}{c}\mathrm{RZ} \text { _VFW } \\
0.014\end{array}$ & $\begin{array}{c}\text { FEI } \\
23.294\end{array}$ & $\begin{array}{c}\text { FEI } \\
18.299\end{array}$ \\
\hline 2 & $\begin{array}{c}\text { LOGAREA } \\
1.218\end{array}$ & $\begin{array}{c}\mathrm{FCD}<0.5 \\
-0.033\end{array}$ & $\begin{array}{c}\text { FEI } \\
24.826\end{array}$ & $\begin{array}{r}\text { FOR2K } \\
0.024\end{array}$ & $\begin{array}{c}\text { BA_SNAG } \\
0.396\end{array}$ & $\begin{array}{c}\text { BA_SNAG } \\
0.368\end{array}$ \\
\hline 3 & $\begin{array}{l}\text { RZ URB } \\
-0.104\end{array}$ & $\begin{array}{c}W \\
-0.035\end{array}$ & $\begin{array}{c}\text { FC2-4 } \\
0.042\end{array}$ & $\begin{array}{c}\text { LOGAREA } \\
0.558\end{array}$ & $\begin{array}{l}\text { TREEDIV } \\
2.623\end{array}$ & $\begin{array}{c}\text { TREEDIV } \\
3.178\end{array}$ \\
\hline 4 & $\begin{array}{c}\text { FOR2K } \\
0.036\end{array}$ & & $\begin{array}{c}\text { FOR2K } \\
0.055\end{array}$ & & $\begin{array}{c}W \\
0.044\end{array}$ & $\begin{array}{c}W \\
0.069\end{array}$ \\
\hline 5 & & & $\begin{array}{c}\text { FORESTRD } \\
-0.142\end{array}$ & & $\begin{array}{c}S \\
0.077\end{array}$ & $\begin{array}{c}S \\
0.109\end{array}$ \\
\hline 6 & & & & & & $\begin{array}{c}\text { LOGAREA } \\
1.013\end{array}$ \\
\hline 7 & & & & . & & $\begin{array}{c}\text { RZ_VFW } \\
0.018\end{array}$ \\
\hline $\mathrm{CCR}^{\mathrm{b}}$ present (\%) & 94.3 & 90.6 & 84.9 & 92.9 & 87.5 & 89.3 \\
\hline CCR absent (\%) & 70.4 & 55.6 & 70.4 & 29.2 & 54.2 & 66.7 \\
\hline CCR overall (\%) & 86.3 & 78.8 & 80.0 & 73.8 & 77.5 & 82.5 \\
\hline Model Chi-square ${ }^{c}$ & $39.4^{* * *}$ & $20.2^{* * *}$ & $45.8 * * *$ & $11.5^{* *}$ & $35.2^{* * *}$ & $43.4^{* * *}$ \\
\hline
\end{tabular}




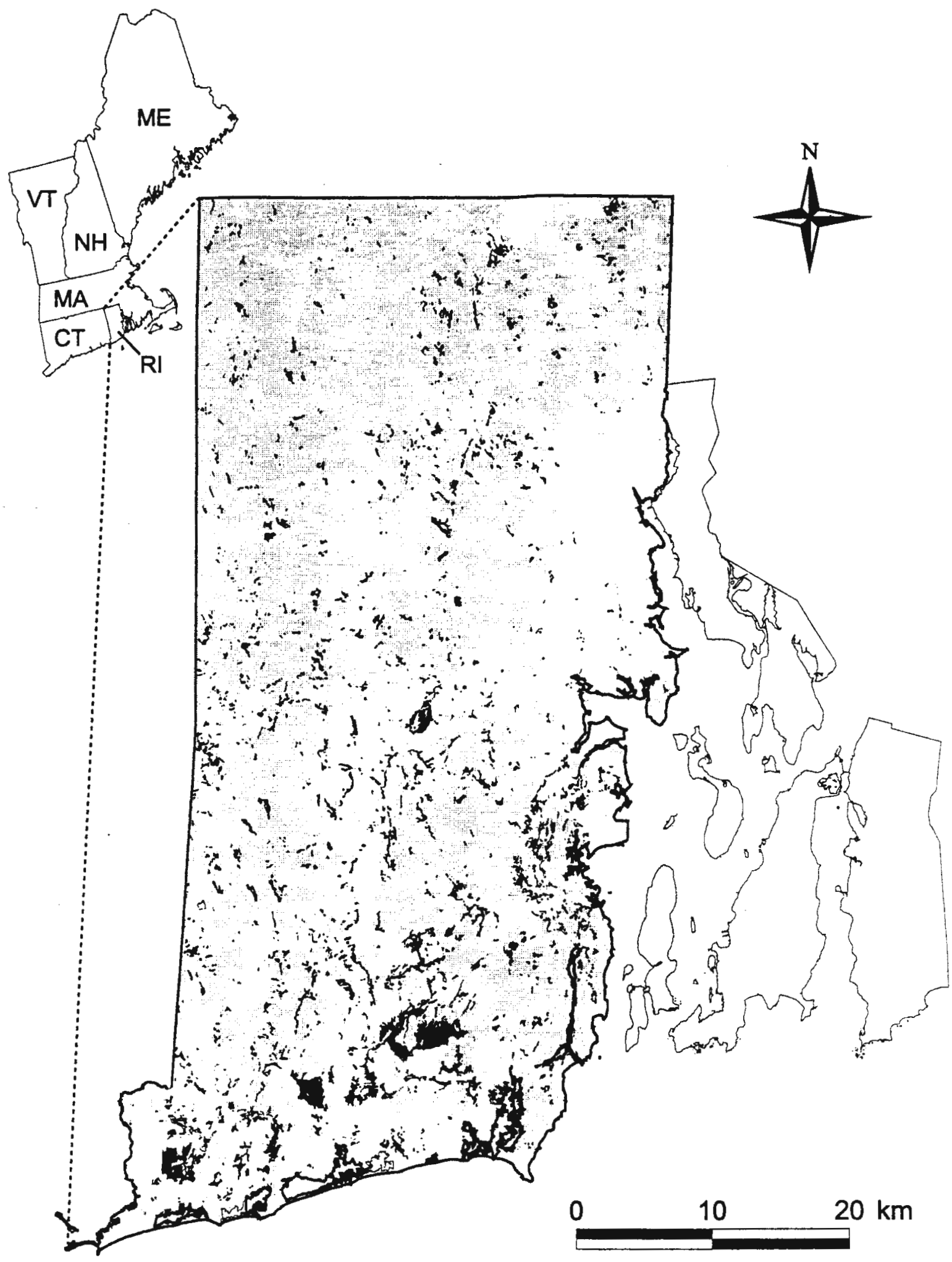

Figure 1. Distribution of very poorly drained forested wetland (black) and other forest cover (gray) in the study area, which comprises most of mainland Rhode Island and is bounded by bold lines. 

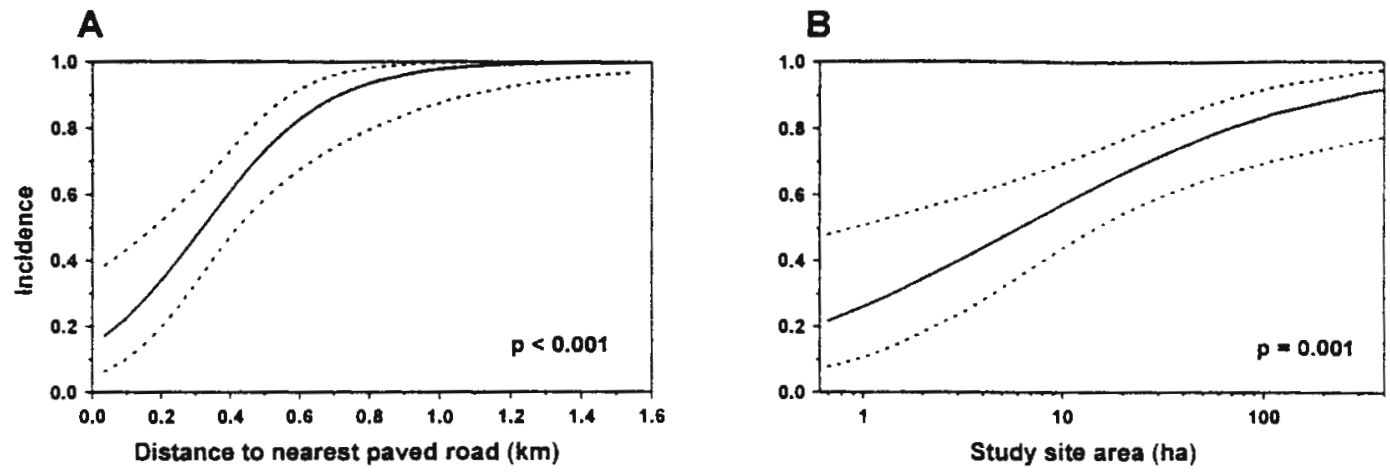

\section{C}

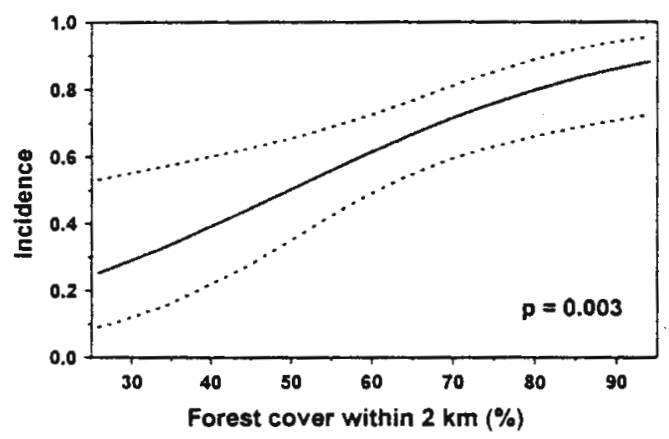

D

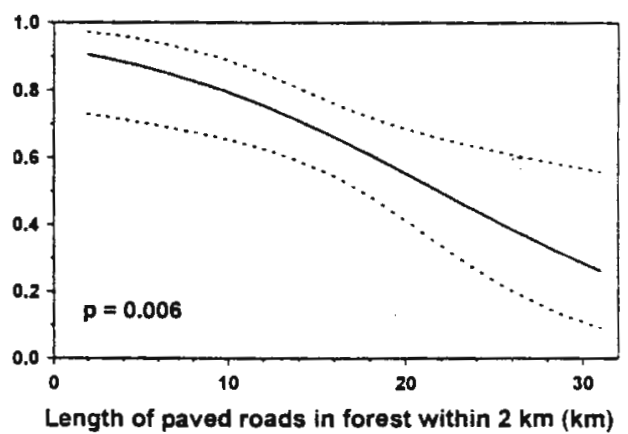

E

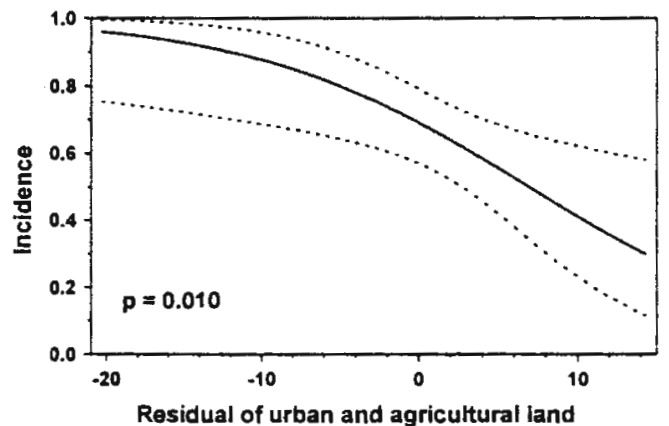

within $2 \mathrm{~km}(\%)$

\section{G}

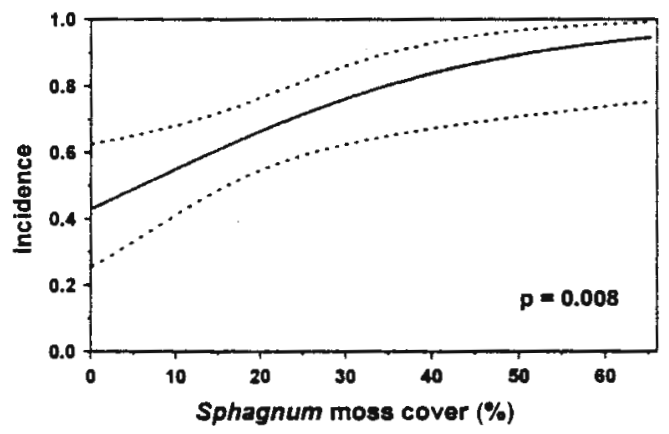

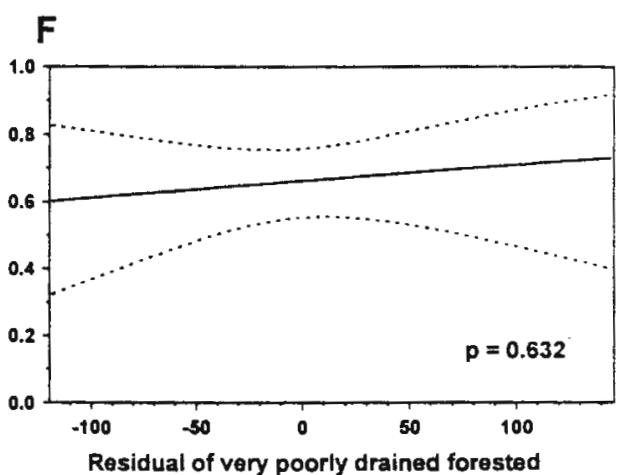

wetland within $2 \mathrm{~km}$ (ha)

H

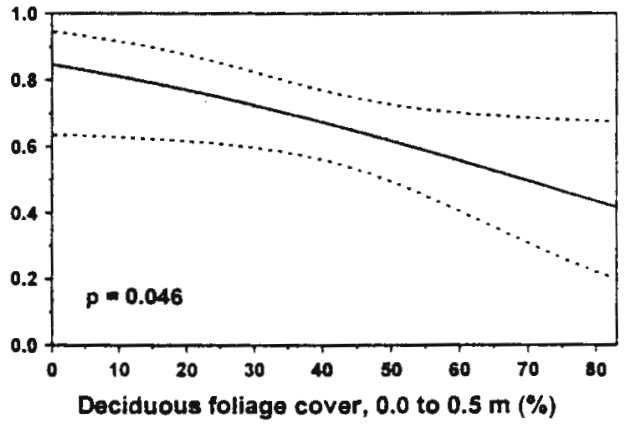

Figure 2. Incidence of Canada Warblers in Rhode Island forested wetlands as a function of landscape and habitat variables. Incidence is the probability of occurrence of Canada Warblers at a survey point for each value of the independent variable. Graphs were created using univariate logistic regression. Dashed lines indicate $95 \%$ confidence intervals. 

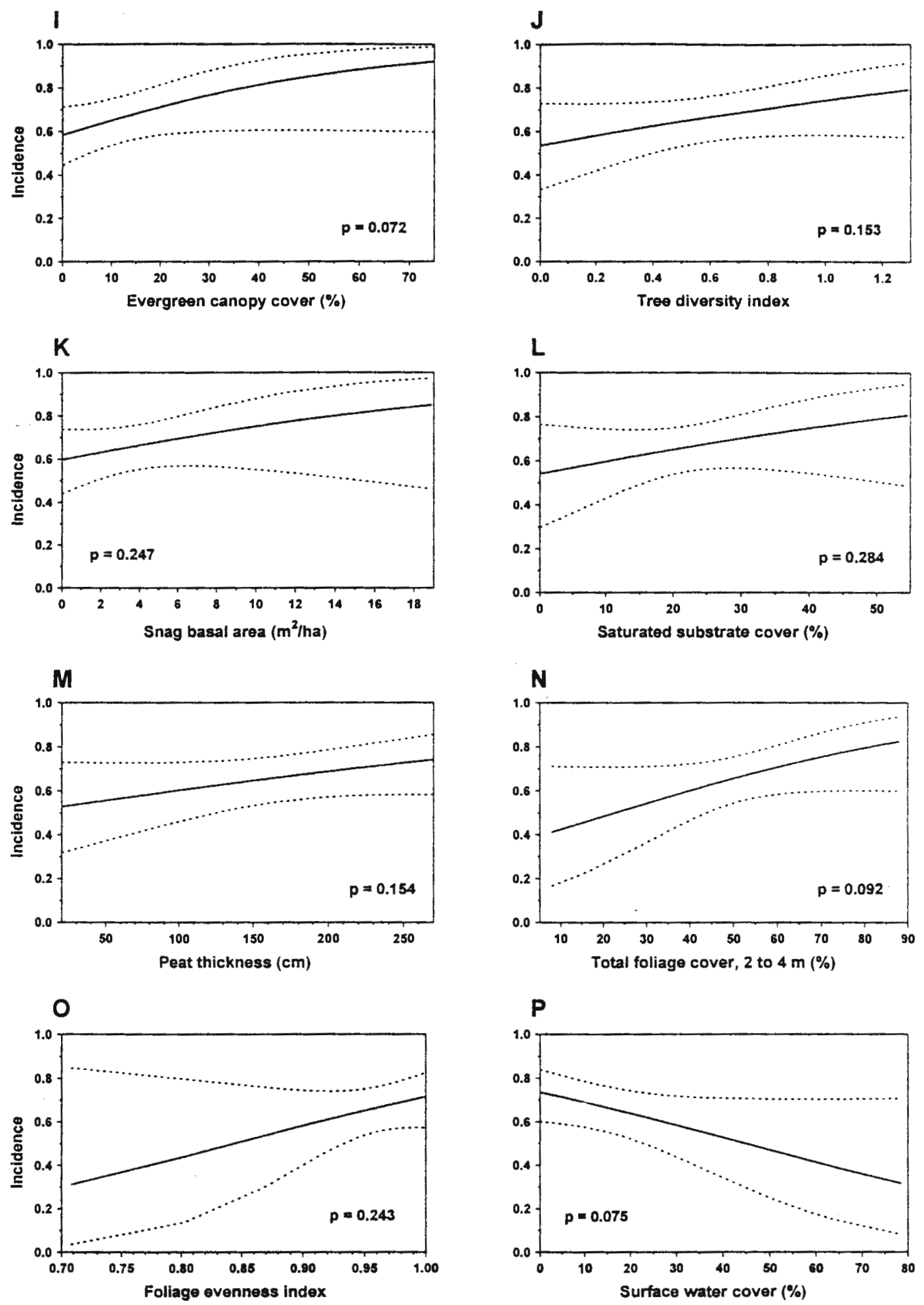

Figure 2. (continued) 
A

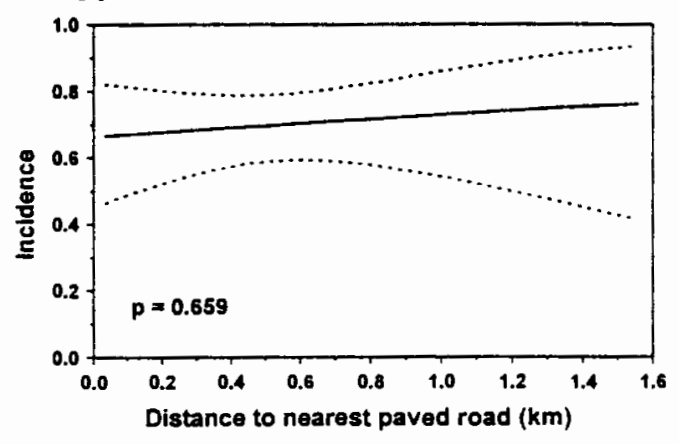

C
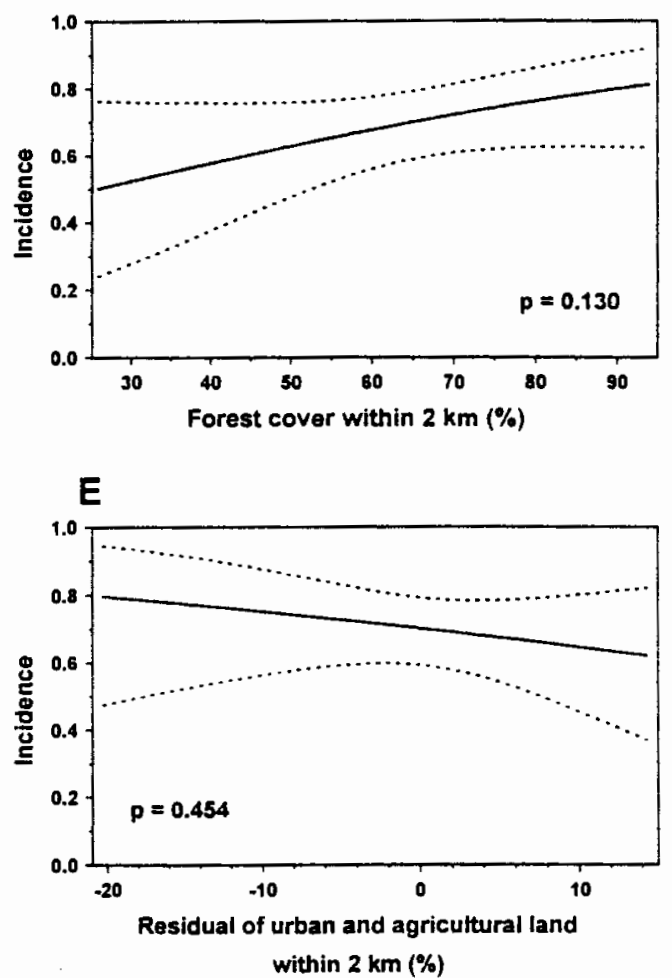

G

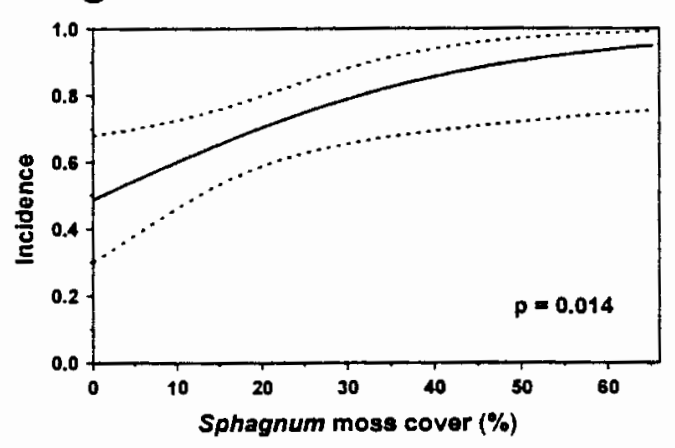

B

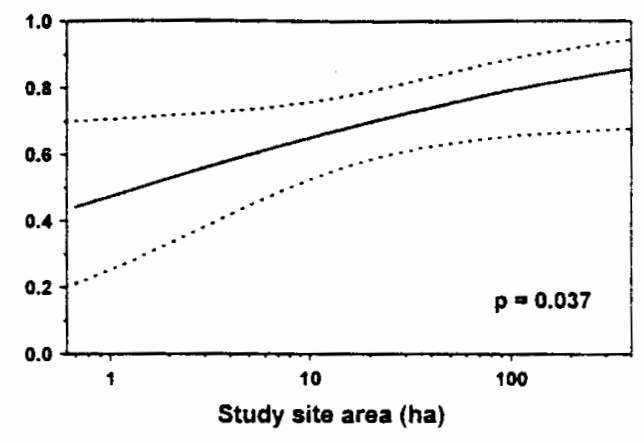

D
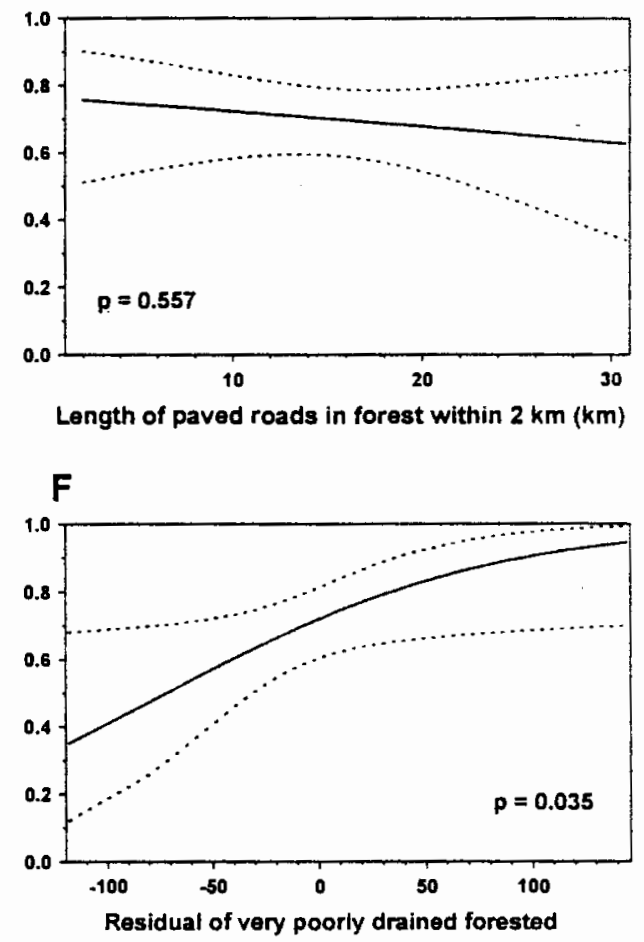

wetland within $2 \mathrm{~km}$ (ha)

H

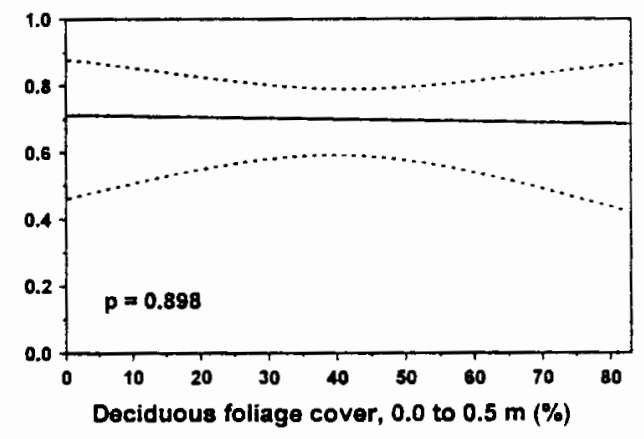

Figure 3. Incidence of Northern Waterthrushes in Rhode Island forested wetlands as a function of landscape and habitat variables. Incidence is the probability of occurrence of Northern Waterthrushes at a survey point for each value of the independent variable. Graphs were created using univariate logistic regression. Dashed lines indicate $95 \%$ confidence intervals. 

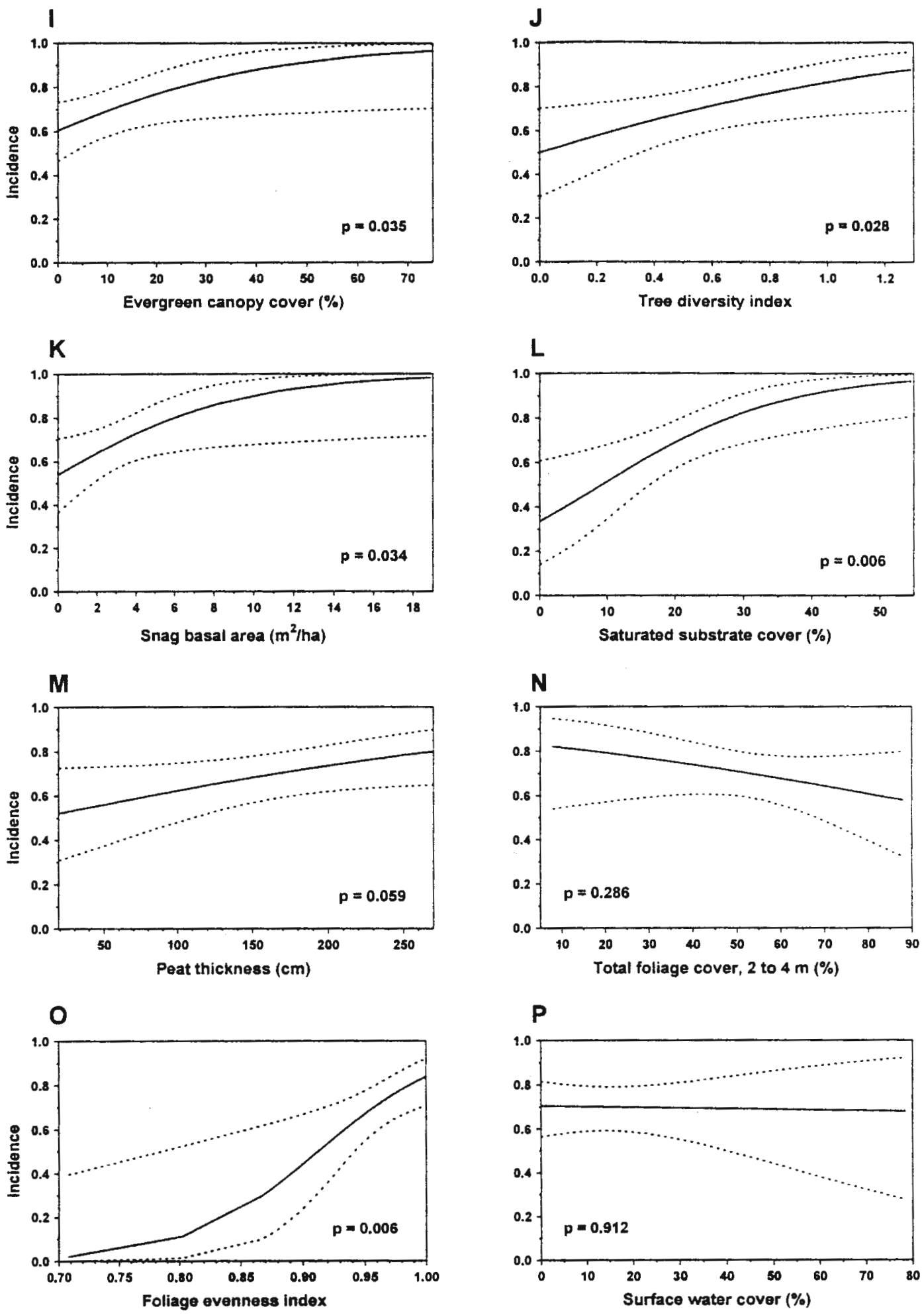

Figure 3. (continued) 
A

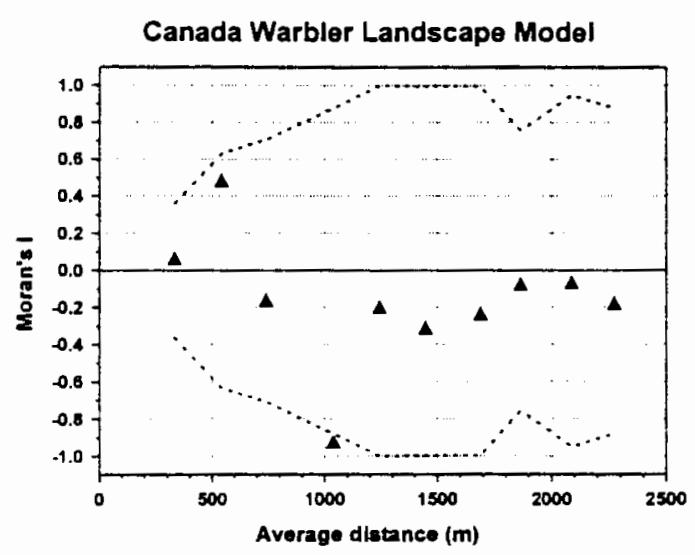

C

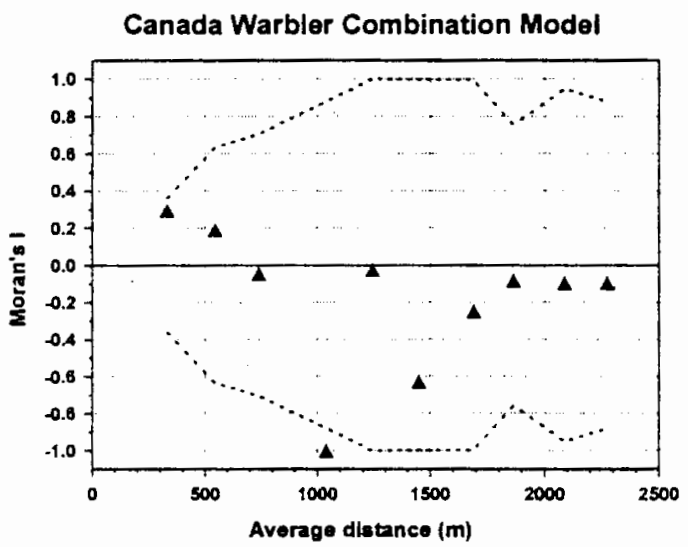

E

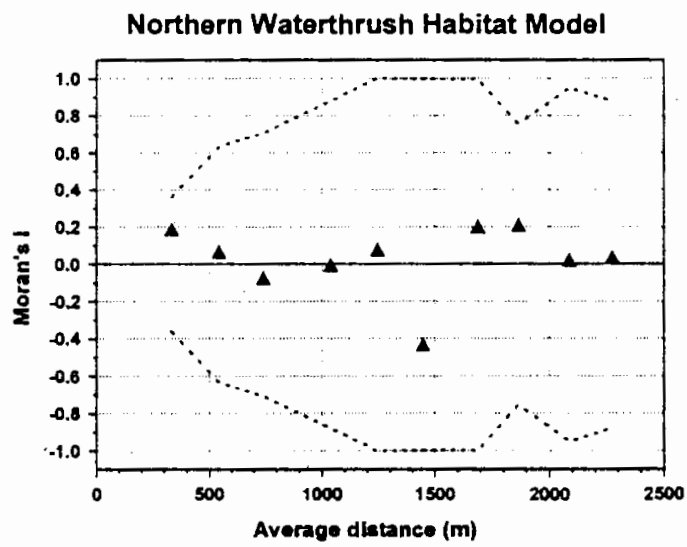

B
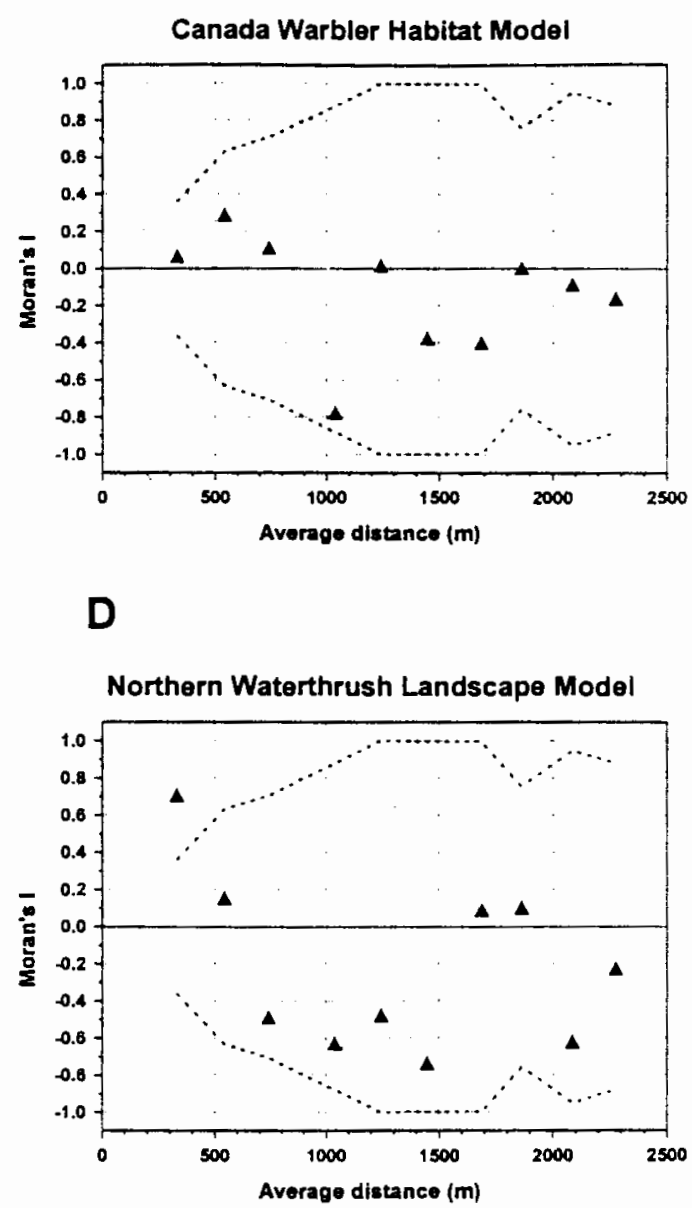

$\mathbf{F}$

Northern Waterthrush Combination Model

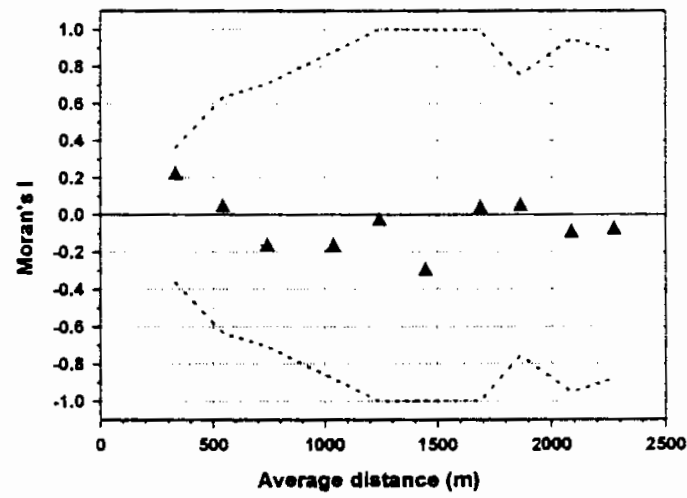

Figure 4. Spatial correlation analyses of the residuals of multivariate logistic regression models, based on Moran's I Coefficient. Dashed lines indicate critical values of I $(p<0.05)$. 
A

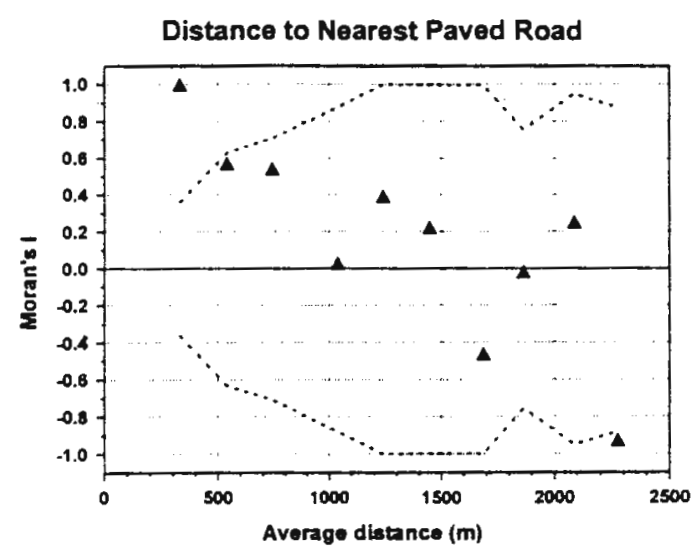

C

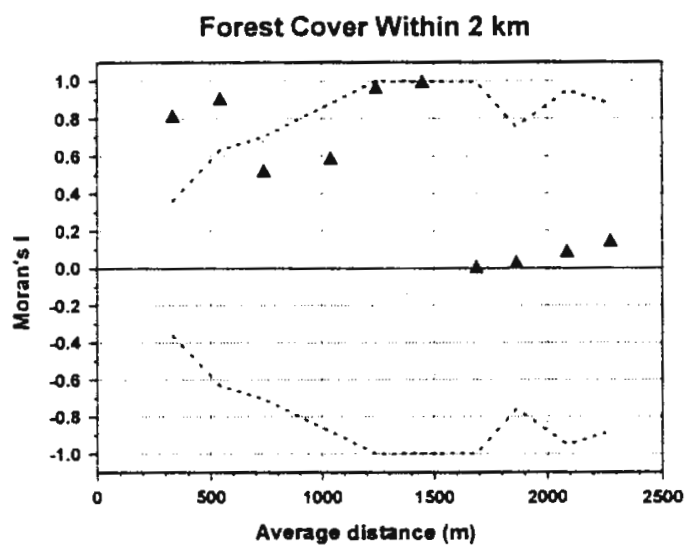

E

Residual Very Poorly Drained Swamp Within $\mathbf{2}$ km

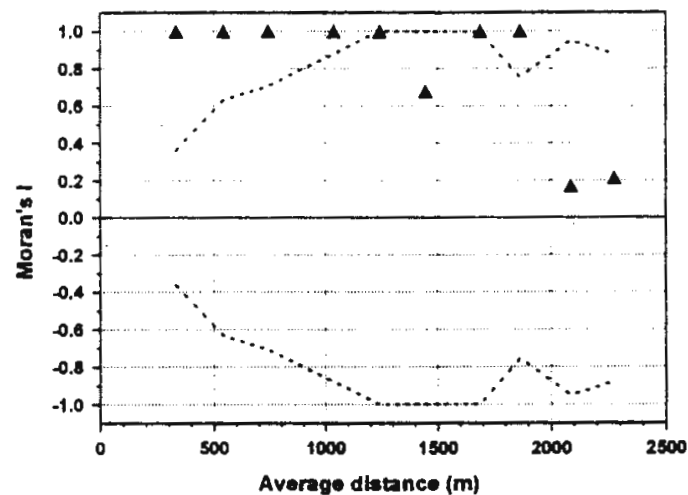

B

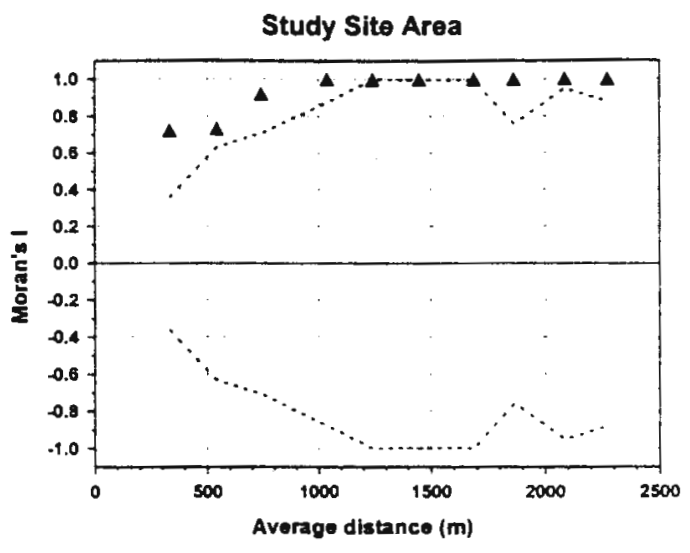

D

Length of Paved Roads in Forest Within $2 \mathrm{~km}$

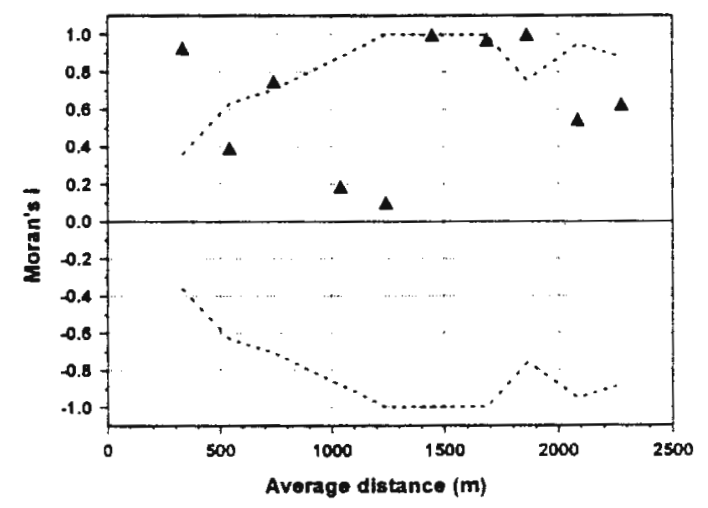

$\mathbf{F}$

Residual of Urban \& Agric. Land Within $2 \mathrm{~km}$

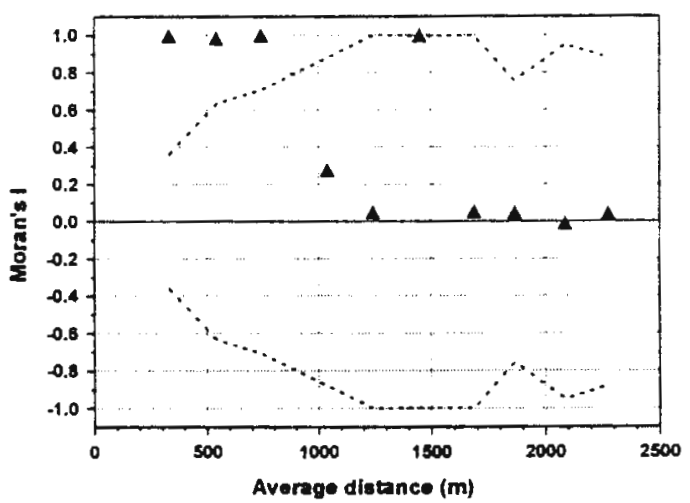

Figure 5. Spatial correlation analyses of landscape variables, based on Moran's I Coefficient. Dashed lines indicate critical values of $I(p<0.05)$. 
A

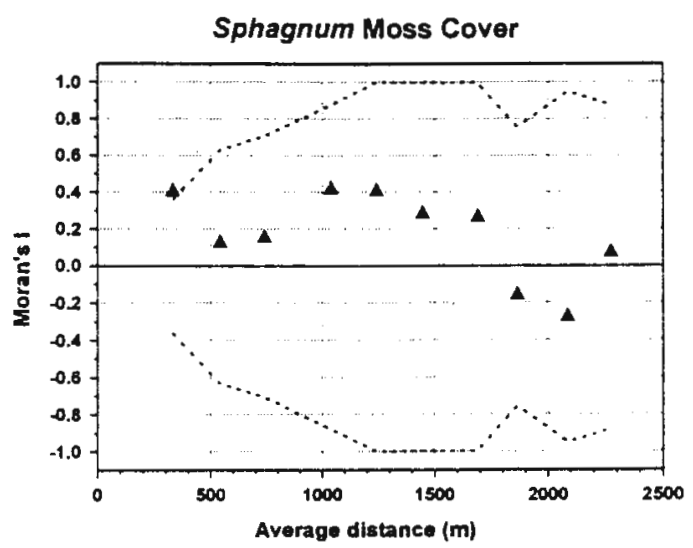

C

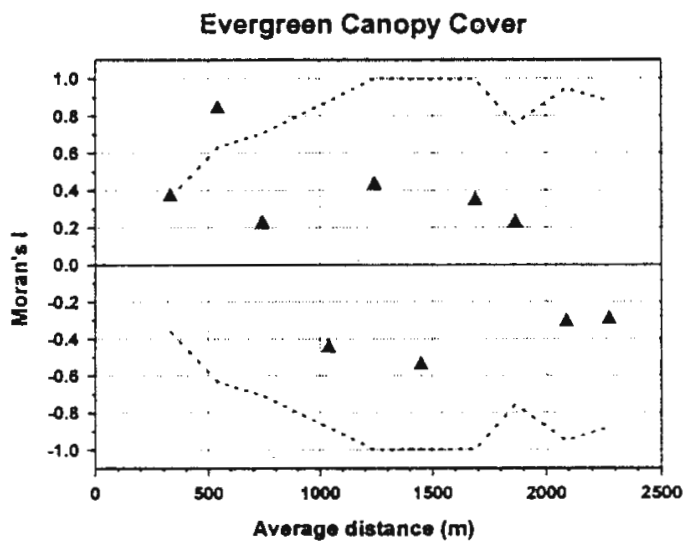

$\mathbf{E}$

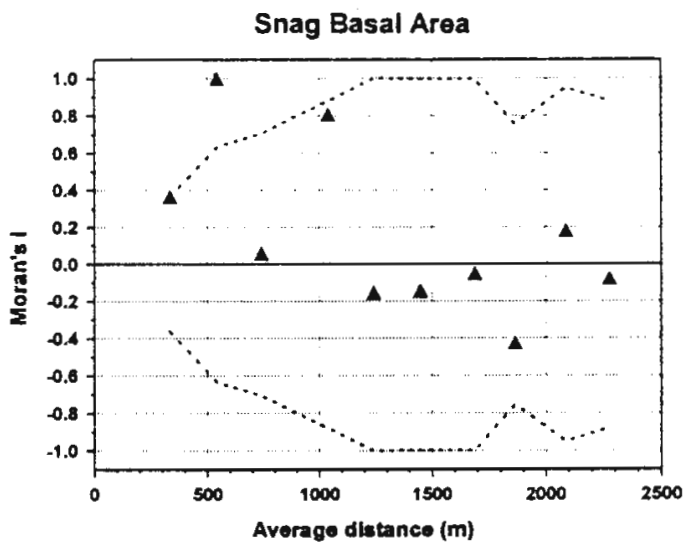

B

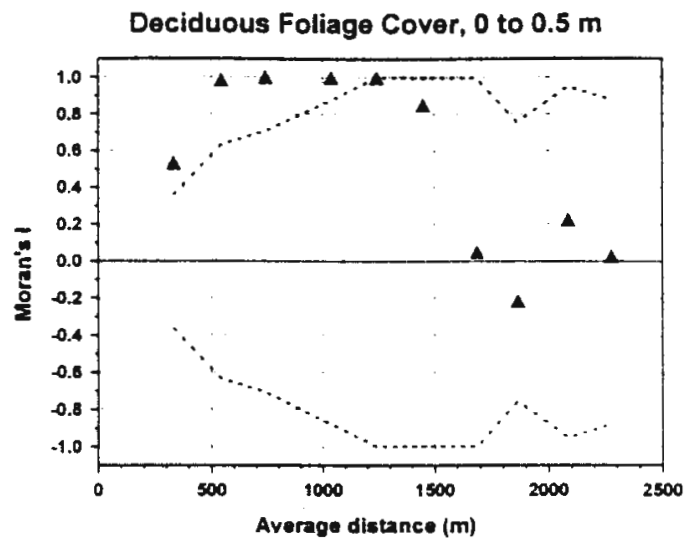

D

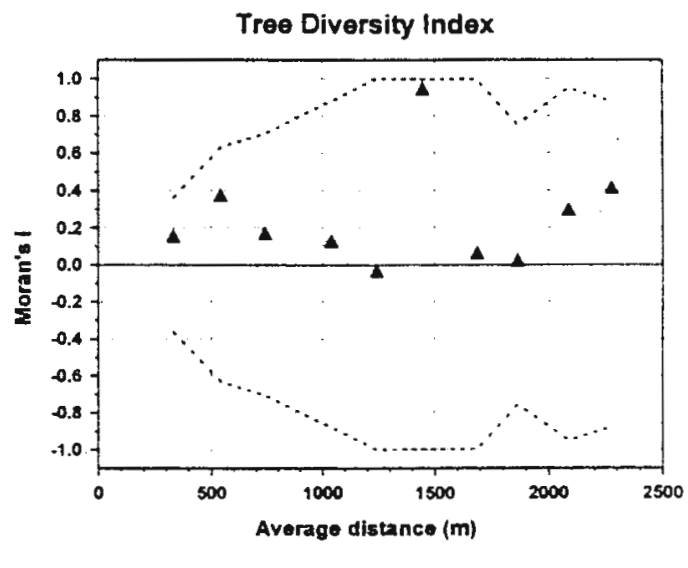

$\mathbf{F}$

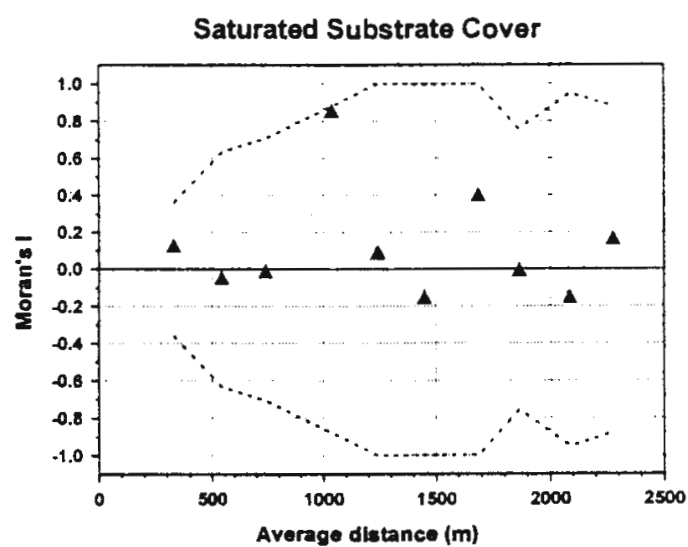

Figure 6. Spatial correlation analyses of habitat variables, based on Moran's I Coefficient. Dashed lines indicate critical values of $I(p<0.05)$. 
A

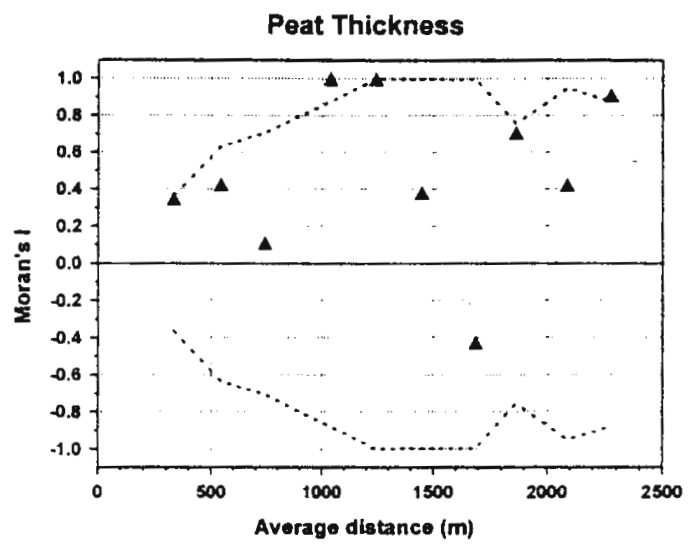

C

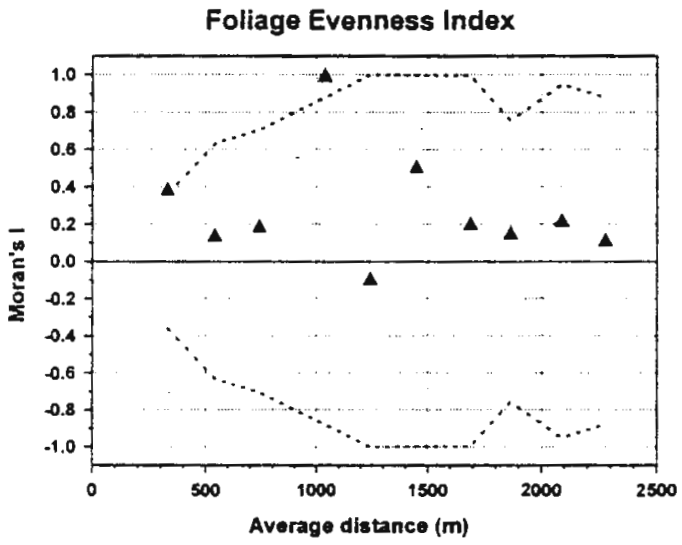

E

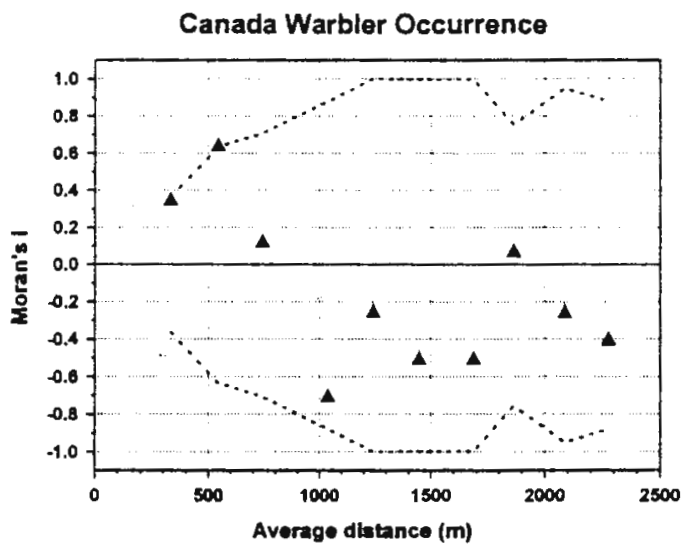

B

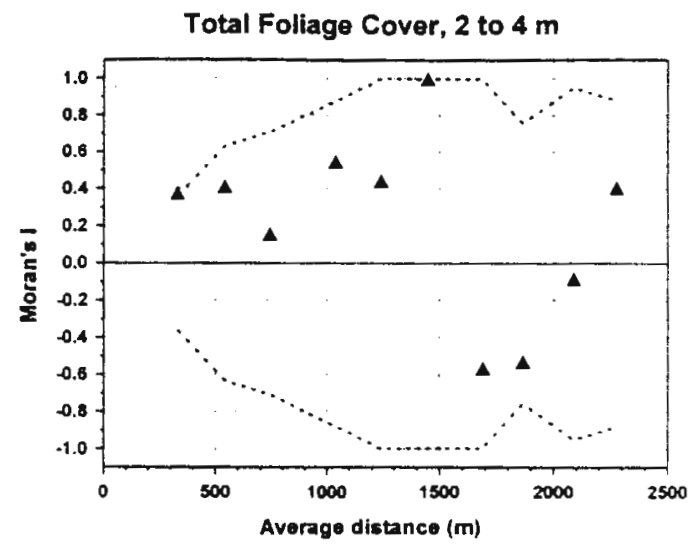

D

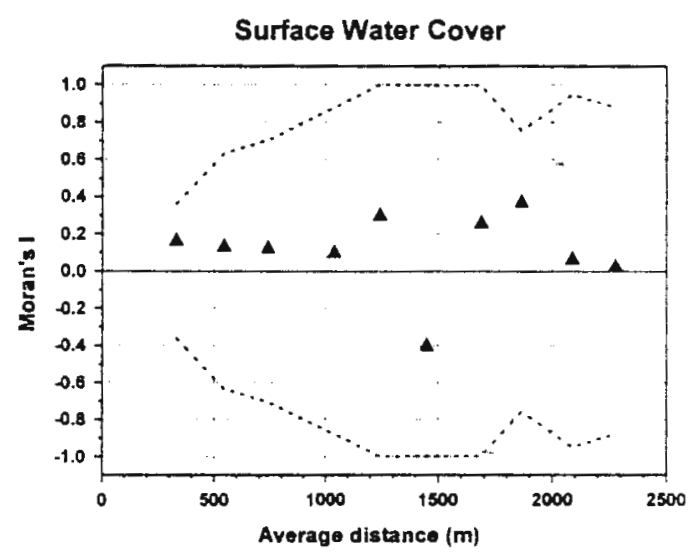

$\mathbf{F}$

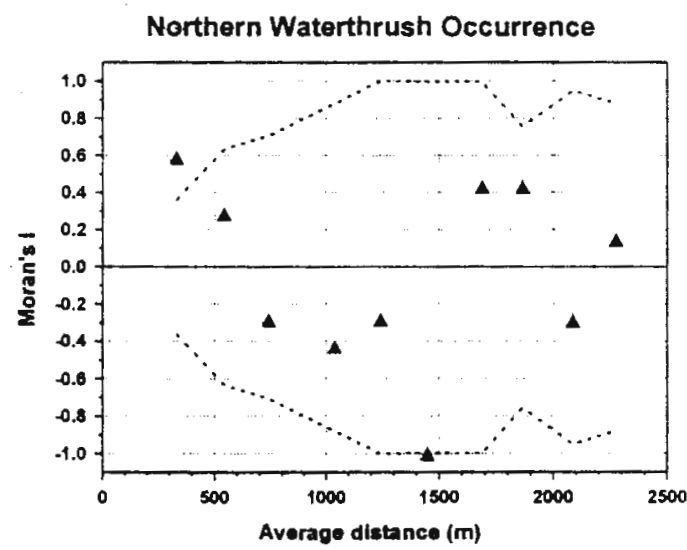

Figure 7. Spatial correlation analyses of habitat and species occurrence variables, based on Moran's I Coefficient. Dashed lines indicate critical values of I $(p<0.05)$. 


\section{BIBLIOGRAPHY}

Ambuel, B., and S.A. Temple. 1983. Area-dependent changes in the bird communities and vegetation of southern Wisconsin forests. Ecology 64:1057-1068.

Askins, R.A., M.J. Philbrick, and D.S. Sugeno. 1987. Relationship between the regional abundance of forest and the composition of forest bird communities. Biological Conservation 39:129-152.

Bent, A.C. 1953. Life histories of North American wood warblers. Smithsonian Institution, U.S. National Museum bulletin 203, Washington, D.C.

Blake, J.G., and J.R. Karr. 1987. Breeding birds of isolated woodlots: area and habitat relationships. Ecology 68:1724-1734.

Bolger, D.T., T.A. Scott, and J.T. Rotenberry. 1997. Breeding bird abundance in an urbanizing landscape in coastal southern California. Conservation Biology $11: 406-421$.

Brittingham, M.C., and S.A. Temple. 1983. Have cowbirds caused forest songbirds to decline? Bioscience 33:31-35.

Cowardin, L.M., V. Carter, F.C. Golet, and E.T. LaRoe. 1979. Classification of wetlands and deepwater habitats of the United States. U.S. Fish and Wildlife Service, Biological Services Program FWS-OBS 79/31.

Craig, R.J. 1984. Comparative foraging ecology of Louisiana and Northem Waterthrushes. Wilson Bulletin 96:173-183.

Craig, R.J. 1985. Comparative habitat use by Louisiana and Northern Waterthrushes. Wilson Bulletin 97:347-355. 
Curson, J., D. Quinn, and D. Beadle. 1994. Warblers of the Americas: an identification guide. Houghton Mifflin Company, New York.

Dunn, J.L., and Garrett, K.L. 1997. A field guide to warblers of North America. Houghton Mifflin Company, New York.

Ehrlich, P.R., D.S. Dobkin, and D. Wheye. 1988. The birder's handbook: a field guide to the natural history of North American birds. Simon and Schuster, New York.

Enser, R.W. 1992. The atlas of breeding birds in Rhode Island. Rhode Island Department of Environmental Management, Providence, Rhode Island.

ESRI. 1998a. ARC/INFO, Version 7.2.1. Environmental Systems Research Institute, Redlands, California.

ESRI. 1998b. ArcView, Version 3.1. Environmental Systems Research Institute, Redlands, California.

Faaborg, J., M. Brittingham, T. Donovan, and J. Blake. 1993. Habitat fragmentation in the Temperate Zone: a perspective for managers. Pages $331-338$ in D.M. Finch and P.W. Stangel, editors. Status and management of Neotropical migratory birds. General technical report RM-229, U.S. Forest Service, Rocky Mountain Forest and Range Experiment Station, Fort Collins, Colorado.

Flather, C.H., and J.R. Sauer. 1996. Using landscape ecology to test hypotheses about large-scale abundance patterns in migratory birds. Ecology 77:28-35.

Forman, R.T.T., and L.E. Alexander. 1998. Roads and their major ecological effects. Annual Review of Ecology and Systematics 29:207-231. 
Freemark, K., and B. Collins. 1992. Landscape ecology of birds breeding in temperate forest fragments. Pages 443-454 in J.M. Hagan III and D.W. Johnston, editors. Ecology and conservation of Neotropical migrant landbirds. Smithsonian Institution Press, Washington, D.C.

Freemark, K.E., and H.G. Merriam. 1986. Importance of area and habitat heterogeneity to bird assemblages in temperate forest fragments. Biological Conservation 36:115141.

Gamma Design Software. 1999. GS ${ }^{+}$3.1. Gamma Design Software, Plainwell, Michigan Golet, F.C., A.J.K. Calhoun, W.R. DeRagon, D.J. Lowry, and A.J. Gold. 1993. Ecology of red maple swamps in the glaciated Northeast: a community profile. Biological report 12, U.S. Fish and Wildlife Service.

Gosselink, J.G., and L.C. Lee. 1989. Cumulative impact assessment in bottomland hardwood forests. Wetlands 9: Special issue.

Griffiths, L.W. 1965. One hundred years of Rhode Island agriculture. Bulletin 378, Rhode Island Agricultural Experiment Station,. Kingston.

Hosmer, D.W., Jr., and S. Lemeshow. 1989. Applied logistic regression. John Wiley and Sons, New York.

Krebs, C.J. 1989. Ecological methodology. Harper and Row, New York.

Litwin, T.S., and C.R. Smith. 1992. Factors influencing the decline of neotropical migrants in a northeastern forest fragment: isolation, fragmentation, or mosaic effects? Pages 483-496 in J.M. Hagan III and D.W. Johnston, editors. Ecology and conservation of Neotropical migrant landbirds. Smithsonian Institution Press, Washington, D.C. 
Lynch, J.F., and D.F. Whigham. 1984. Effects of forest fragmentation on breeding bird communities in Maryland, U.S.A. Biological Conservation 28:287-324.

Merrow, J.S. 1990. The influence of area and habitat on the avian community in red maple swamps of southern Rhode Island. M.S. Thesis, University of Rhode Island, Kingston.

Mitsch, W.J., and J.G. Gosselink. 1993. Wetlands. Van Nostrand Reinhold, New York.

Paton, P.W.C. 1994. The effect of edge on avian nest success: how strong is the evidence? Conservation Biology 8:17-26.

Pendleton, G.W. 1995. Effects of sampling strategy, detection probability, and independence of counts on the use of point counts. Pages 131-133 in C.J. Ralph, J. R. Sauer, and S. Droege, editors. Monitoring bird populations by point counts. General technical report PSW-GTR-149, U.S. Forest Service, Pacific Southwest Research Station, Albany, Califomia.

Qi, Y., and J. Wu. 1996. Effects of changing spatial resolution on the results of landscape pattem analysis using spatial autocorrelation indices. Landscape Ecology 11:3949.

Ralph, C.J., J.R. Sauer, and S. Droege. 1995. Managing and monitoring birds using point counts: standards and applications. Pages 161-168 in C.J. Ralph, J. R. Sauer, and S. Droege, editors. Monitoring bird populations by point counts. General technical report PSW-GTR-149, U.S. Forest Service, Pacific Southwest Research Station, Albany, California.

Rector, D. 1981. Soil survey of Rhode Island. U.S. Soil Conservation Service, West Warwick, Rhode Island. 
Reijnen, R., R. Foppen, C. ter Braak, and J. Thissen. 1995. The effects of car traffic on breeding bird populations in woodland. III. Reduction of density in relation to the proximity of main roads. Journal of Applied Ecology 32:187-202.

Robbins, C.S. 1979. Effect of forest fragmentation on bird populations. Pages 142-163 in R.M. DeGraaf and K.E. Evans, editors. Proceedings of the workshop: management of north central and northeastern forests for nongame birds. General technical report NC-51, U.S. Forest Service, North Central Forest Experiment Station, St. Paul, Minnesota.

Robbins, C.S., D.K. Dawson, and B.A. Dowell. 1989. Habitat area requirements of breeding forest birds of the Middle Atlantic States. Wildlife Monographs 103:134.

Sauer, J. R., J. E. Hines, G. Gough, I. Thomas, and B. G. Peterjohn. 1997. The North American Breeding Bird Survey results and analysis. Version 96.4. Patuxent Wildlife Research Center, Laurel, Maryland.

SPSS, Inc. 1998. SYSTAT 8.0 for Windows. SPSS, Inc., Chicago, Illinois.

StatSoft, Inc. 1998. STATISTICA for Windows. StatSoft, Inc., Tulsa, Oklahoma.

Swift, B.L., J.S. Larson, and R.M. DeGraaf. 1984. Relationships of breeding bird density and diversity to habitat variables in forested wetlands. Wilson Bulletin 96:48-59.

Underwood, A.J. 1997. Experiments in ecology: their logical design and interpretation using analysis of variance. Cambridge University Press. Cambridge, United Kingdom.

Van Horn, M.A., R.M. Gentry, and J. Faaborg. 1995. Patterns of Ovenbird (Seiurus aurocapillus) pairing success in Missouri forest tracts. Auk 112:98-106. 
Vickery, P.D., M.L. Hunter, Jr., and S.M. Melvin. 1994. Effects of habitat area on the distribution of grassland birds. Conservation Biology 8:1087-1097.

Wenny, D.G., R.L. Clawson, J. Faaborg, and S.L. Sheriff. 1993. Population density, habitat selection and minimum area requirements of three forest-interior warblers in central Missouri. Condor 95:968-979.

Whitcomb, R.F., J.F. Lynch, M.K. Klimkiewicz, C.S. Robbins, B.L. Whitcomb, and D. Bystrak. 1981. Effects of forest fragmentation on avifauna of the eastern deciduous forest. Pages 125-205 in R.L. Burgess and D.M. Sharpe, editors. Forest island dynamics in man-dominated landscapes. Springer-Verlag, New York.

Wilcove, D.S. 1985. Nest predation in forest tracts and the decline of migratory songbirds. Ecology 66:1211-1214.

Wright, W.R., and E.H. Sautter. 1979. Soils of Rhode Island landscapes. Bulletin 429, Rhode Island Agricultural Experiment Station, Kingston. 